\title{
MODEL PENGEMBANGAN INDUSTRI PERIKANAN TERPADU: (STUDI KASUS DI WILAYAH PENGEMBANGAN UTAMA III, JAWA TENGAH)
}

\author{
Agus Heri Purnomo, Siti Hajar Suryawati, Yayan Hikmayani dan Elly Reswati')
} \begin{abstract}
ABSTRAK
Penelitian ini mencakup suatu rangkaian kegiatan studi lapang, analisis sosio-ekonomis dan pemodelan, dilaksanakan pada tahun 2002, dengan tujuan untuk merancang suatu model pengembangan industri perikanan. Contoh kasus 5 kabupaten di Propinsi Jawa Tengah (Rembang, Pati, Blora, Jepara dan Kudus) diacu untuk membangun model tersebut di lokasi penelitian, yang secara induktif dapat dikembangkan menjadi model umum yang berlaku di wilayah lain. Data yang dipergunakan dalam kegiatan penelitian ini dikumpulkan melalui teknik partisipatif, meliputi: penggalian informasi sekunder, observasi lapang, dan diskusi/konsultasi Data tersebut dianalisis menurut kerangka sistem agribisnis yang mempertautkan sejumlah input dan output yang terkait dengan industri perikanan yang dimodelkan dalam penelitian ini Input dimaksud adalah semua faktor relevan, baik yang bersifat fisik maupun sosial, sedangkan output adalah tujuan-tujuan dari pengembangan industri perikanan, yang dalam penelitian ini diukur menurut 4 kriteria yaitu profitabilitas, stabilitas, kontinuitas, dan ekuitabilitas. Hasil penelitian ini menunjukkan bahwa sejalan dengan otonomi daerah, kabupaten-kabupaten telah menyusun program eksploitasi sumberdaya yang dikaitkan dengan pengembangan industri perikanan, yang pada umumnya dilaksanakan tanpa mengindahkan interaksi antara eksploitasi sumberdaya di satu tempat dengan kinerja industri perikanan di tempat lain. Faktor-faktor fisik maupun sosial yang teridentifikasi dalam penelitian ini menunjukkan bahwa model pengembangan industri perikanan terpadu antar kawasan/kabupaten merupakan alternatif yang perlu dipertimbangkan penerapannya. Spesialisasi peran untuk masing-masing kabupaten, yang diperlukan untuk mengoptimalkan perkembangan industri perikanan dalam suatu model terpadu, misalnya: prioritas perikanan laut di Rembang dan Pati sedangkan penangkapan sungai di Blora. Model ini dapat diadaptasikan ke wilayah lain, dengan asumsi bahwa kabupaten-kabupaten/wilayah lain di Indonesia pada umumnya mempunyai kecenderungan yang sama dalam menyikapi otonomi.
\end{abstract}

\begin{abstract}
A model for the development of integrated fisheries industry (A case study in the 'Wilayah Pengembangan Utama III, Central Java). By: Agus Heri Purnomo, Siti Hajar Suryawati, Yayan Hikmayani and Elly Reswati
\end{abstract}

This research covers a series of field work activities, socio-economic analysis, and modeling, all of which were carried out in 2002 and aimed at establishing a model for the development of fisheries industry. The case of 5 districts in Central Java (Rembang, pati, Blora, Jepara, and Kudus) was taken as the study case and inductively used to develop the model. Data were collected using participatory approach, which includes obtaining secondary information, field observation, and discusion as well as consultation. The data were then analysed according to agribusiness framework which connects a number of inputs, both physical and social ones, and outputs related to the modeled fishery industry. The inputs were all relevant factors while the outputs were the universal objectives of fishery development, which in this research were measured according 4 criteria, namely profitability, stability, continuity, and equitability. The primary finding of this research includes information that in line with the implementation of decentralization policy, regencies have formulated programs on fisheries resource exploitation, which seemingly have been done with ignorance on the interaction between resource exploitation in a particular location and the performance of related industries in other places. Physical and social factors identified in this research show that integrated fishery industry models are worth considering. In order to allow optimal fisheries industrial developmet within the location covered, the research has suggested different industrial role assignment to each regency, based on 4 criteria mentioned above, e.g Rembang dan Pati should concentrate on marine capture while Blora on river capture fishery. Assuming that many other locations face similar problems caused by decentralization, the adaptation of this model in other places in Indonesia may be considered.

KEYWORDS: social economy, modeling, fisheries industry development. 


\section{PENDAHULUAN}

Sehubungan dengan besarnya peran ekonomi dan sosial yang dimainkan oleh subsektor perikanan, pemerintah telah memberikan perhatian yang besar pada pengembangan sub-sektor ini. Namun demikian, meskipun dinilai membawa hasil-hasil positif, pengembangan perikanan besar-besaran yang didukung penuh oleh pemerintah itu juga memunculkan masalah dalam bentuk inefisiensi (eksploitasi berlebih) yang terkait dengan adanya dikotomi nelayan kecil dan industri (Fauzi, 1999). Perkembangan terakhir menunjukkan bahwa masalah perikanan cenderung menjadi lebih kompleks sejalan dengan penerapan otonomi daerah. Daerah-daerah dengan tradisi pengusahaan perikanan seperti Jawa Barat, Jawa Tengah, dan Jawa Timur seolah berlomba untuk mengeksploitasi sumberdaya perikanannya tanpa memperhatikan keterbatasan sumberdaya. Hal ini menunjukkan bahwa otonomi daerah berpeluang untuk memperbesar dimensi konflik, dari hanya antar skala industri menjadi antar skala industri dan antar daerah, sehingga inefisiensi ekonomi menjadi lebih besar

Pengembangan kawasan-kawasan industri perikanan terpadu, dimana kepentingan dari kutubkutub konflik tersebut dapat diakomodasikan dengan lebih baik merupakan salah satu solusi terhadap kondisi sebagaimana disebutkan di atas. Melalui pengaturan-pengaturan yang difasilitasi oleh sebuah model kawasan industri terpadu, manfaat yang diperoleh dari sumberdaya perikanan akan dapat dimaksimalkan. Pertanyaan yang kemudian muncul adalah 'bagaimana bentuk model yang ideal untuk keadaan daerah yang beragam?'. Meskipun samasama menguasai laut yang paling produktif di Indonesia (Anonim, 1995), kabupaten-kabupaten di Jawa Barat, Jawa Tengah, dan Jawa Timur, misalnya, memiliki profil yang berbeda-beda, baik dalam aspek biofisika sumberdayanya, sosial-kemasyarakatannya, maupun prasarana publiknya. Perbedaanperbedaan profil tersebut menuntut adanya bentukbentuk model kawasan industri perikanan harus dirancang spesifik untuk daerah yang berbeda.

Dari berbagai literatur yang membahas faktorfaktor yang harus dipertimbangkan dalam pengembangan industri perikanan, misalnya Payne (1973) yang memfokuskan pada perikanan Lautan Hindia, Brainerd (1989) yang mengemukakan kasus Afrika, Zerner (1992) yang mengambil contoh perairan waduk, Bailey (1992) yang membahas perikanan budidaya, dan Townsley (1998) yang menyoroti aspek-aspek sosial, dapat disarikan 4 kriteria penting yang harus dipertimbangkan dalam pengembangan perikanan. Kriteria tersebut mencakup profitabilitas pemerataan, stabilitas, dan keberlanjutan.
Penelitian ini dirancang berdasarkan tinjauan di atas, dengan tujuan untuk merumuskan suatu pola atau model bagi pengembangan industri perikanan, yang mengacu pada pada keadaan atau status dari faktor-faktor / kriteria sebagaimana tersebut di atas.

\section{METODE}

\section{Pendekatan, pengumpulan data, dan aspek yang diamati}

Pendekatan yang digunakan dalam penelitian ini adalah pemodelan yang didasarkan pada data primer dan sekunder yang diperoleh dari studi kasus 5 kabupaten di Jawa Tengah yaitu Rembang, Blora, Pati Jepara, dan Kudus. Pembangunan model tersebut dilakukan dengan mengikuti tahapan sebagai berikut:

1. Persiapan, dimana tujuan pembangunan perikanan dan potensi yang tersedia untuk mewujudkan tujuan tersebut diidentifikasi

2. Formulasi konsep model, dimana pola pencapaian tujuan tersebut secara konseptual dirumuskan

3. Operasionalisasi, dimana data-data empiris dimasukkan kedalam model konseptual untuk mendapatkan model operasional

4. Validasi, dimana model operasional diikomunikasikan ke stakeholders untuk mendapatkan koreksi terhadap data, informasi, maupun model yang dirumuskan melalui pendekatan di atas

Selain hasil identifikasi potensi dan tujuan-tujuan pembangunan, acuan lain yang dipergunakan untuk membangun konsep model dalam penelitian ini adalah kerangka agribisnis (Saragih, 2001), dimana pengembangan industri diusahakan dengan memperhatikan keterkaitan antar subsistem yang ada. Dalam industri perikanan, subsistem-subsistem dimaksud mencakup berbagai kegiatan usaha, di antaranya penangkapan, budidaya ikan, pengolahan. dan pemasaran

Data untuk kepentingan penelitian dikumpulkan melalui proses partisipatif yang dilaksanakan selama periode April-September 2002. Pada tahap pertama, dikumpulkan data-data sekunder yang tercatat pada berbagai sumber, yaitu Dinas-dinas Perikanan, Dinas Perindustrian, Kantor Statistik, Bappeda, Kantor Bupati. Pada tahap berikutnya, data-data tersebut diklarifikasi kebenarannya melalui wawancara/diskusi dengan narasumber kunci, yaitu individu atau kelompok yang berpengetahuan atau ahli pada informasi tertentu. Dalam hal ini, untuk setiap informasi dilakukan klarifikasi terhadap minimal (3) tiga tokoh kunci. Untuk informasi-informasi tertentu, klarifikasi tersebut dilakukan juga melalui peninjauan ke lapangan 


\section{Jurnal Penelitian Perikanan Indonesia Volume 9 Nomor 6 Tahun 2003}

Jenis data/informasi yang dikumpulkan meliput aktor-faktor fisik dan sosial yang terkait dengan pengembangan segenap subsistem agribisnis yaitu subsistem produksi, pengolahan, pemasa keadaan kelembagaan. Faktor fisik meliputi keadaan sumberdaya (misal: jenis dan kelimpahan sumbenan sedangan yang tersedia) dan prasarana pendukung, faktor sosial meliputi parameter-parar

demografi, SDM, dan sebagainya.

\section{Analisis}

Data yang telah diverifikasi melalui wawancara dengan narasumber kunci dan peninjauan lapang emudian dipergunakan dalam pembentukan kerangka maupun bangunan operasional dari mode ang dikembangkan melalui tahapan tersebut di atas. Mengacu pada pentahapan tersebut, analisis dilakukan sesuai dengan konteks pada masingmasing tahapan, sebagian data dianalisis dengan statistik deskriptif dan grafis, dan sebagian dianalisis dengan metoda pembobotan faktor (Subagio, 2000). Dalam hal metode pembobotan faktor, nilai-nilai dari kriteria distandarisasi melalui skoring, yang memungkinkan penyeragaman unit nilai dari masingmasing kriteria. Misalnya, nilai tertinggi setara dengan skor 100 sedangkan nilai terendah setara dengan skor o. Dalam penelitian ini, diasumsikan bahwa tidak ada kriteria yang perlu mendapatkan bobot lebih besar atau lebih kecil; dengan demikian, skor total dari sebuah pilihan merupakan penjumlahan dari skor seluruh kriteria yang terkait dengan pilihan tersebut Argumentasi tentang resiko diakibatkan oleh kesalahan asumsi juga disajikan dalam laporan ini untuk memberikan justifikasi tambahan bagi kelayakan penerapan model yang dikembangkan dalam penelitian ini.

\section{Ruang Lingkup dan Batasan}

Pemodelan yang dimaksud dalam laporan ini terbatasi oleh tugas pokok dan fungsi Pusat Riset Pengolahan Produk dan Sosial Ekonomi Kelautan dan Perikanan (PRPPSE) yang tidak memungkinkan dilakukannya uji aplikasi model untuk melakukan pengukuran kinerja model di lapangan. Namun demikian, analisis dalam laporan ini diharapkan mampu memberikan gambaran tentang beberapa kemungkinan yang terkait dengan kinerja lapangan dari model tersebut.

Model ini mengambil contoh kasus pengembangan industri perikanan yang terjadi di suatu kawasan di awa Tengah; namun demikian, diharapkan bahwa uatu kesimpulan umum yang dapat diaplikasikan ecara lebih luas dapat diperoleh, dengan asumsi us tersebut dapat mewakili sebagian besar gambaran permasalahan di kawasan-kawasan lain di Indonesia. Dalam hal ini, kawasan yang dipilih sebagai sebut adalah 5 kabupaten $^{1}$ tergabung $^{2}$ contoh kasus tersebutambangan Utama III di Jawa dalam Wilayah Pabupaten Rembang, Kabupaten KuTengah, yaitu Kabupaten Kepara, Kabupaten Blora, dan dus, Kabupaten Jepan demikian pengambilan data Kabupaten Pati. Dengan dilakukan di wilayah tersebut. empiris sebagian dilakukan lain yang memiliki disamping di wilayah-wilayah lain yantri perikanan keterkaitan dengan pengembangan industri perkanan di lokasi utama penelitian.

Pembatasan lain adalah dalam hal cakupan analisis. Dalam hal ini, tinjauan lebih mendalam tentang beberapa aspek yang diperkirakan turut berpengaruh terhadap aplikasi dari model, seperti misalnya faktor sosio-antropologi, diharapkan akan diperoleh dari hasil penelitian lain yang dilakukan oleh PRPPSE

\section{HASIL DAN BAHASAN}

\section{Identifikasi Tujuan, Kondisi dan Potensi Perikanan}

Bagi kabupaten-kabupaten di lokasi utama penelitian, tujuan yang pada umumnya tercantum dalam perencanaan/program pembangunan perikanan adalah memberdayakan nelayan, meningkatkan ekspor hasil perikanan, meningkatkan konsumsi ikan, dan meningkatkan pengendalian pemanfaatan sumberdaya ikan. Penerapan otonomi daerah telah menyebabkan masing-masing wilayah otonom cenderung berlomba untuk meningkatkan eksploitasi sumberdaya dalam rangka meningkatkan perekonomian daerahnya, termasuk peningkatan eksploitasi sumberdaya perikanan. Hal ini, misalnya, tercermin dari percepatan realisasi pembangunan sarana dan prasarana yang berkaitan dengan penangkapan, termasuk pengembangan tempattempat pendaratan dan peningkatan kapasitas armada penangkap

Berbeda dengan kecenderungan perubahan yang terjadi pada tingkat upaya eksploitasinya, data produksi perikanan laut dalam kurun waktu 1997-2001 tidak menunjukkan kenaikan yang berarti, bahkan ada kecenderungan penurunan produksi di sebagian besar kabupaten dalam cakupan wilayah penelitian. Hal ini

Berdasarkan informasi yang berkembang pada saat akhir kegiatan penelitian ini penggabungan wilayah pengembangan perikanan tersebut telah berubah, tetapi hal tersebut tidak merubah esensi dari hasil penelitian ini/Based on the budding information at the end of this research along with developing fisheries areas' have changed, but this does not alter the essence from this research. 


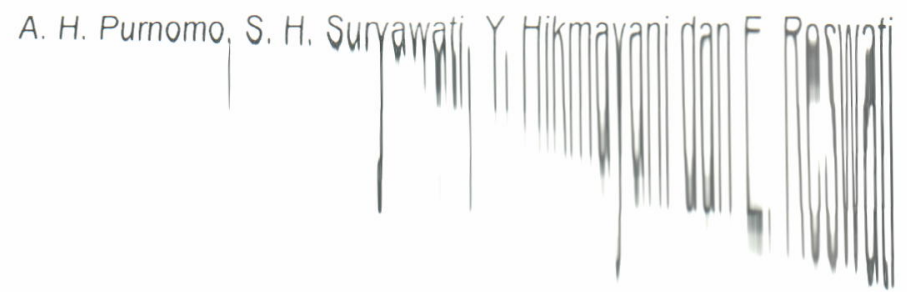

merupakan salah satu indikasi telah berlangsungnya Selain ditandai oleh gejala tangkap sumberdaya perikanan laut di lokasi penelitian jebih, kondisi variasi produksi tahunan antarkan juga menunjukkan dilihat pada Gambar 1. Hal ini dapat perkembangan produr 1, yang menunjukkan terakhir. Kabupaten Jepa panjang pantai yang tideara, meskipun memiliki dan Rembang, ternyata menunbeda jauh dengan Pati tahunan yang jauh dibawah kedua kabupaten
tetangga tersebut.
Terlepas dariadanya perkembangan

menggembirakan pacerkembangan yang kurang sacara umum dapat dikataka tahun terakhir. perikanan laut di wilayah inikan bahwa potensi produksi dari tahun ke tahun sangat besar. Catatan kabupaten di wilayah ini menunjukkan bahwa dua menempati posisi teratas daitu Pati dan Rembang. di Propinsi Jawa Tengah.

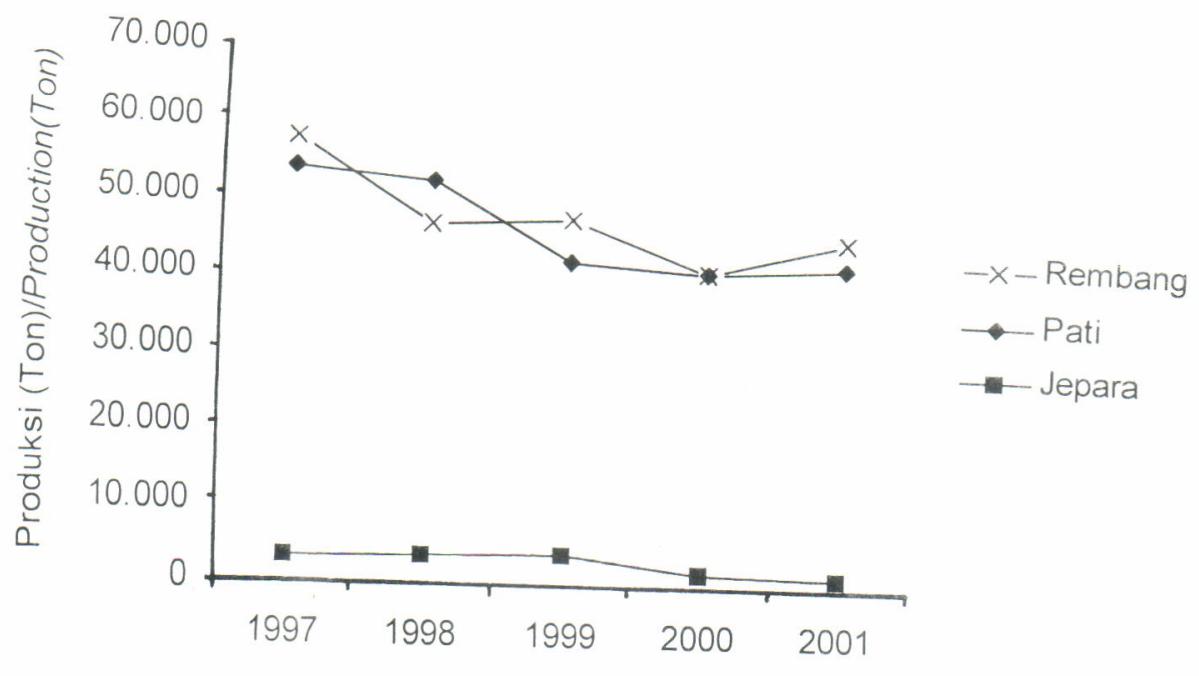

Tahun/Years

Gambar 1. Produksi ikan laut tahunan di Rembang, Pati, dan Jepara Figure 1. Annual marine fish production in Rembang, Pati, and Jepara

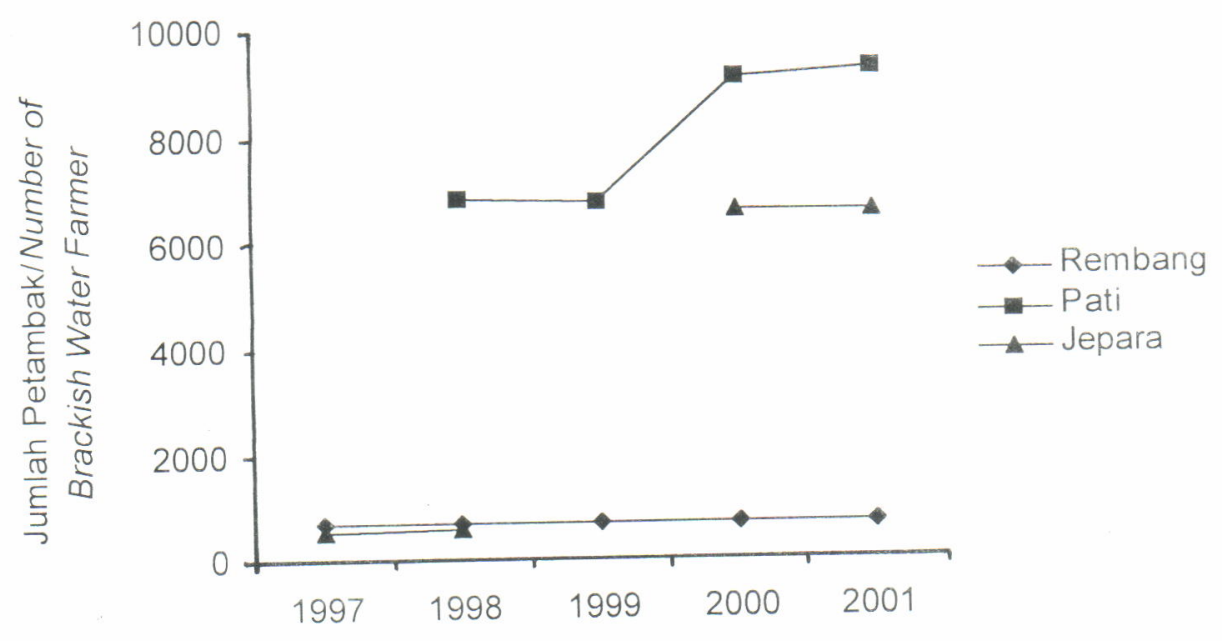

Tahun/Years

Gambar 2. Perkembangan jumlah petani tambak, Tahun 1997 - 2001 Figure 2. Development of number of brackishwater farmers, Year 1997- 2001 


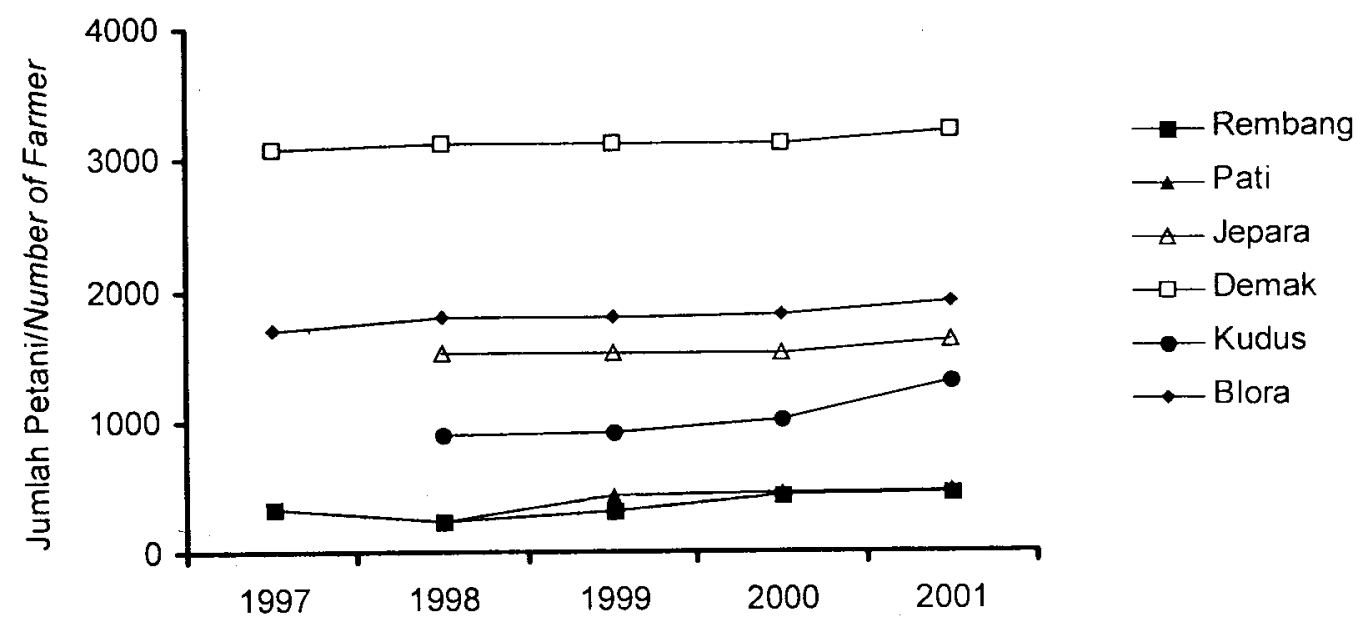

Tahun/Years

Gambar 3. Perkembangan Jumlah Pembudidaya Kolam Budidaya, Tahun 97 - 01

Figure 3. Development of Number of Freshwater Fish Farmers, Year $97-01$

Gambaran potensi yang besar namun tidak termanfaatkan secara optimal terlihat pada sumberdaya pertambakan. Penurunan produksi terjadi terutama sebagai akibat berkembang masalah penyakit, yang diyakini oleh banyak pihak terkait dengan pola budidaya yang terlalu intensif. Akibat krisis ekonomi yang terjadi hampir bersamaan dengan periode serangan penyakit, ongkos produksi melambung terlalu tinggi bagi sebagian besar petambak sehingga usaha budidaya menjadi semakin tidak menguntungkan. Akibatnya, luasan tambak potensial yang diusahakan sangat menurun. Namun demikian, sebagaimana pada perikanan laut, potensi pertambakan di wilayah ini dapat dikategorikan sangat besar. Pada tahun 2001, tercatat produksi 16.224 ton. Sebagai gambaran tentang besarnya potensi usaha pertambakan, Gambar 2 mempresentasikan keterlibatan masyarakat nelayan pada jenis usaha tersebut.

Secara umum, dapat dikatakan bahwa perkembangan perikanan air tawar tertinggal dibanding perikanan laut ataupun perikanan tambak. Meskipun

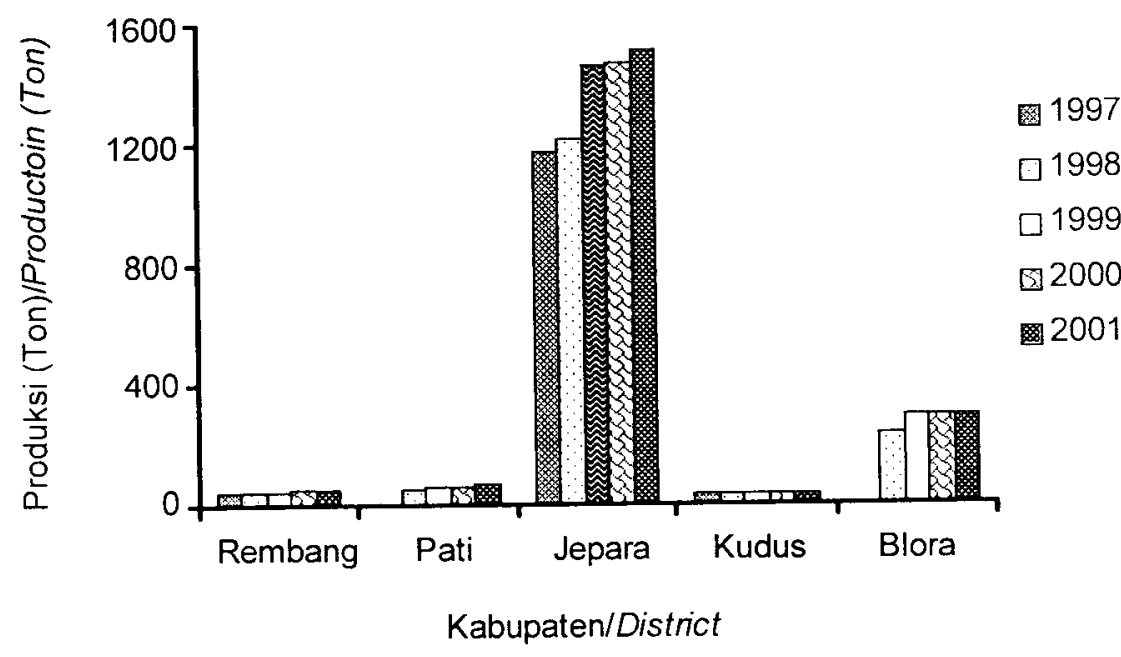

Gambar 4. Perbandingan produksi ikan sungai antar kabupaten, Tahun 77-01

Figure 4. Inter-regency comparison of river fish production, Year 77-01 
demikian, sebagaimana diilustrasikan melalui Gambar 3 , tampak adanya kecenderungan yang positif pada beberapa tahun terakhir, dimana jumlah petani kolam budidaya meningkat dari waktu ke waktu.

Kondisi perikanan umum, khususnya sungai di lokasi penelitian, juga menunjukkan perkembangan yang positif meskipun ditandai pula oleh hal negatif berupa perbedaan yang cukup besar dalam hal produksi di antara kabupaten-kabupaten yang dijadikan lokasi penelitian. Meskipun mempunyai total panjang sungai yang tidak jauh berbeda dengan kabupatenkabupaten lain di sekitarnya, Kabupaten Jepara mampu memproduksi ikan sungai jauh melebihi produksi Pati, Rembang, Demak, dan Blora (lihat Gambar 4).

\section{Kondisi dan Potensi Industri Pengolahan Ikan}

Dua kabupaten di WPU III, yaitu Rembang dan Pati, merupakan wilayah-wilayah dimana industri

\section{Kondisi Sarana, Prasarana dan Kelembagaan Pendukung Industri Perikanan}

Prasarana, sarana, dan keberadaan lembagalembaga pendukung merupakan faktor penting berikutnya yang berperan dalam mempengaruhi perkembangan industri perikanan, tidak hanya untuk pengembangan sisi hulu, melainkan juga untuk aspekaspek industri perikanan pada sisi hilir. Prasarana dimaksud di antaranya adaiah Jalan, Transportasi, TPI/ PPI, dan lembaga keuangan. Tabel 1 menunjukkan kondisi prasarana yang tersedia di masing-masing kabupaten di lokasi penelitian.

\section{Perumusan (Formulasi) Konsep Model}

Sebagaimana disebutkan dalam metodologi, kerangka pikir yang digunakan dalam penelitian ini adalah agribisnis, yang berarti bahwa pengembangan industri perikanan harus mencakup penyehatan dan optimalisasi kinerja setiap komponen bisnis dari

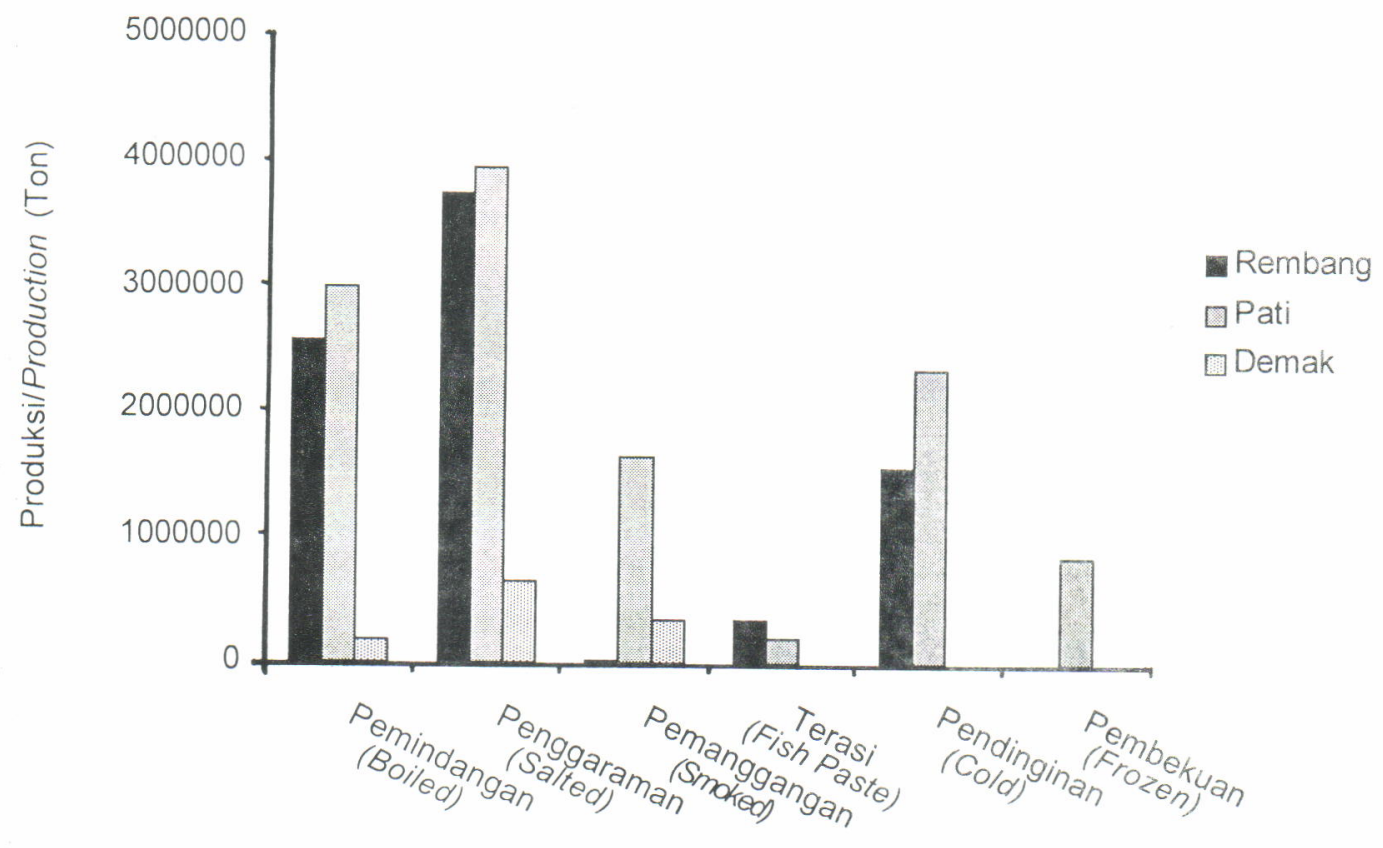

Jenis Olahan/Processing Type

Gambar 5. Perbandingan produksi hasil olahan ikan berdasar jenis olahannya, Tahun 2001

Figure 5. Comparison of processed fish production by processing types, Year 2001

pengolahan merupakan subsistem industri perikanan yang menonjol. Bahkan, dibanding kabupaten lain yang berada di luarnya, misalnya Demak, produksi ikan olahan di kedua kabupaten tersebut jauh lebih tinggi. Gambar 5 menunjukkan fakta-fakta tersebut. industri dimaksud, mulai dari kegiatan industri hulu sampai ke hilir. Kegiatan yang termasuk dalam kelompok kegiatan hulu dimaksud di antaranya adalah kegiatan produksi ikan segar, baik melalui kegiatan penangkapan maupun melalui usaha budidaya 
Tabel 1. Sarana, prasarana, dan lembaga pendukung industri perikanan di lokasi penelitian tahun 2001 Table 1. Facilities, infrastructure, and supporting institution for fisheries industry in the research locations, year 2001

\begin{tabular}{|c|c|c|c|c|c|}
\hline \multirow{2}{*}{$\begin{array}{c}\text { Jenis Prasarana (Type } \\
\text { of infrastructure ) }\end{array}$} & \multicolumn{5}{|c|}{ Kabupaten/District } \\
\hline & Rembang & Pati & Demak & Jepara & Blora \\
\hline Jalan/road & baik/good & baik/good & baik/good & baik/good & baik/good \\
\hline $\begin{array}{l}\text { Transportasi/ } \\
\text { Transportation }\end{array}$ & baik/good & baik/good & baik/good & baik/good & baik/good \\
\hline $\begin{array}{l}\text { KUD/Village } \\
\text { Cooperatives }\end{array}$ & 3 & 0 & 2 & 4 & 0 \\
\hline $\begin{array}{l}\text { Lembaga Keuangan/Bank } \\
\text { Umum (Bank) }\end{array}$ & 8 & 16 & 6 & 14 & 5 \\
\hline Galangan Kapal/Docking & 0 & 0 & 0 & 0 & 0 \\
\hline Cold Storage & & & & & 0 \\
\hline TPI/Fish Auction Place & 13 & 5 & 4 & 11 & 0 \\
\hline PPI/Fishing Port & 1 & 1 & 1 & 1 & 0 \\
\hline Pabrik Es//ce Mfg. & $\begin{array}{l}4(65 \text { ton/hari) } \\
4(65 \text { ton/days) }\end{array}$ & $\begin{array}{l}2 \text { (40 ton/hari) } \\
2 \text { (40 ton/days) }\end{array}$ & 0 & $\begin{array}{l}2(40 \text { ton/hari) } \\
2 \text { (40 ton/days) }\end{array}$ & $\begin{array}{l}2 \text { (25 ton/hari) } \\
2 \text { ( } 25 \text { ton/days) }\end{array}$ \\
\hline Listrik/Electricity, $\mathrm{KWH}$ & 64.885 .252 & 199.107 .457 & 105.012 .354 & 177.843 .963 & 45.879 .342 \\
\hline $\begin{array}{l}\text { Air (Kap. Produksi)/Water } \\
\text { Capacity }\left(\mathrm{m}^{3}\right)\end{array}$ & 3.430 .440 & 3.781 .419 & 4.325 .000 & 3.545 .000 & - \\
\hline $\begin{array}{l}\text { Jaringan Pasar/ } \\
\text { Marketing Channels }\end{array}$ & baik/good & baik/good & baik/good & baik/good & lemah/poor \\
\hline $\begin{array}{l}\text { Kelompok Nelayan/ } \\
\text { Fisherman Group }\end{array}$ & 147 & nd & nd & nd & 0 \\
\hline $\begin{array}{l}\text { Pasar ikan/ } \\
\text { Fish Market }\end{array}$ & 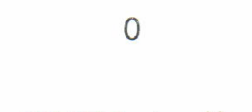 & 1 & 0 & 0 & 0 \\
\hline $\begin{array}{l}\text { Kapasitas Balai Benih } \\
\text { Ikan/Unit Pembenihan } \\
\text { Rakyat/Capacity of } \\
\text { Breeding Installation Unit }\end{array}$ & $\begin{array}{l}37.674 \text { ekor/th } \\
\text { fish/years }\end{array}$ & $\begin{array}{l}7.340 .400 \\
\text { ekor/th } \\
\text { fish/years }\end{array}$ & nd & $\begin{array}{l}923.000 \\
\text { ekor/th } \\
\text { fish/years }\end{array}$ & $\begin{array}{l}1.491 .000 \\
\text { ekor/th } \\
\text { fish/years }\end{array}$ \\
\hline $\begin{array}{l}\text { Depo Udang/ikan } \\
\text { Shrimp/Fish Depot }\end{array}$ & 0 & 32 unit & 0 & 0 & 0 \\
\hline
\end{tabular}

Keterangan (Note): $\mathrm{nd}=$ tidak ada data (no data)

Sumber (Source):

1. Laporan Tahunan Dinas Kelautan dan Perikanan Kab. Pati tahun 1997-2001

2. Data Statistik Perikanan Rembang tahun 2001

3. Lap. Tahunan Dinas Kelautan dan Perikanan Kab. Demak Tahun 1997-2001

4. Lap. Tahunan Dinas Pertanian Kab. Jepara 1997-2001

5. Lap. Tahunan Dinas Pertanian Kab. Blora Tahun 2001 
sedangkan termasuk sisi hilirnya adalah kegiatankegiatan pemasaran. Menurut Saragih (2001), hal penting yang perlu mendapatkan perhatian dalam konsep agribisnis perikanan adalah perbaikanperbaikan pada aspek teknologi, kelembagaan, organisasi bisnis, pasar, SDM dan infrastruktur.

Berdasarkan fakta empiris sebagaimana dipaparkan di atas, dapat dirangkum beberapa hal yang diidentifikasi perlu mendapatkan perhatian dalam pengembangan model industri perikanan di lokasi penelitian berdasarkan kosep agribisnis tersebut di atas. Beberapa hal tersebut di antaranya adalah bahwa

1. Dengan hanya mengandalkan daerah penangkapan yang selama ini dieksploitasi (di laut), peluang peningkatan produksi ikan untuk wilayah-wilayah dalam lokasi penelitian ini kecil.

2. Di sisi lain, terdapat peluang untuk meningkatkan produksi ikan darat, baik melalui kegiatan penangkapan di perairan umum maupun melalui kegiatan budidaya

3. Terdapat berbagai kendala untuk mengembangkan pasar internasional, nasional, maupun regional.

4. Terdapat potensi pasar lokal yang masih dormant, yang selama ini lebih banyak mengkonsumsi sumber protein dalam bentuk lain.

5. Terdapat jaringan kegiatan industri perikanan yang telah terjalin, baik berbagai jenis kegiatan di dalam satu kabupaten, maupun antar kabupaten dalam cakupan wilayah penelitian

6. Dengan memanfaatkan jaringan yang telah ada, terdapat peluang untuk membangun pola/model industri perikanan yang mempunyai kinerja dan ketahanan yang baik, yaitu dengan mengoptimalkan kelebihan dan memperbaiki kekurangan-kekurangannya.

Untuk mendapatkan gambaran yang lebih jelas tentang hal-hal penting tersebut di atas, berikut ini merupakan bahasan lebih mendalam dari masingmasing.

\section{Keadaan Tangkap Lebih Pada Perikanan Laut}

Kecenderungan penurunan produksi yang terjadi secara serentak di wilayah-wilayah penelitian, dan wilayah-wilayah lain di 3 kabupaten berpantai di lokasi penelitian pada tahun-tahun terakhir ini (Gambar 1) dapat dipandang sebagai suatu indikasi bahwa di daerah penangkapan dimana kapal-kapal ikan dari wilayah tersebut melaut, telah terjadi tangkap lebih. Dengan demikian, penambahan jumlah atau peningkatan efektivitas tangkap akan berakibat pada penurunan produksi. Indikasi status tangkap lebih di perairan ini dikuatkan oleh berbagai laporan ilmiah, misalnya laporan yang menyebutkan bahwa tingkat eksploitasi perairan di sebelah utara Pulau Jawa, dimana kapal-kapal dari ketiga kabupaten tersebut melaut, telah mencapai tidak kurang dari $30 \%$ di atas kapasitas maksimalnya (Martosubroto et al, 1991).

Sementara itu, kabupaten-kabupaten dalam cakupan penelitian ini, bersama dengan sejumlah kabupaten lain di Jawa Tengah, terlibat dalam program pengembangan TPI, yang pada umumnya disertai dengan rencana-rencana peningkatan upaya tangkap ( Anonim 1998; Anonim, 2001a). Peningkatan upaya tersebut dilakukan dalam berbagai bentuk, termasuk penambahan jumlah kapal, peningkatan efektivitas tangkap, perpanjangan waktu layar, dan beberapa lainnya. Perencanaan-perencanaan pengembangan industri perikanan di berbagai tempat, termasuk yang terjadi pada lokasi-lokasi dalam cakupan wilayah penelitian ini pada umumnya didasarkan pada asumsi bahwa terdapat korelasi positif antara volume produksi dengan tingkat upaya Berdasarkan asumsi tersebut, program-program yang ada telah mengalokasikan sumberdaya (baik finansial maupun sosial), untuk merealisasikan peningkatan upaya penangkapan.

Ketidaktepatan asumsi di atas dapat dijelaskan berdasarkan ilustrasi yang ditunjukkan pada Gambar 6. Gambar tersebut memprediksikan output dari peningkatan jumlah armada (atau bentuk lain peningkatan upaya) pada kondisi sumberdaya telah tereksploitasi melebihi batas kemampuan maksimalnya (MSY). Pada kondisi itu, ekspansi armada (atau bentuk peningkatan upaya lainnya), dalam jangka pendek (short run) akan menyebabkan terjadinya kenaikan produksi karena stok ikan yang ada di dalam air masih memiliki tingkat kepadatan yang sama dengan waktu sebelumnya². Pada waktuwaktu sesudahnya, stok akan menurun akibat eksploitasi yang melebihi laju pemulihan, yang dilakukan pada waktu sebelumnya. Akibatnya, hasil tangkap untuk tingkat upaya yang sama akan menurun. Dengan demikian, asumsi korelasi positif antara tingkat upaya dengan hasil tangkap sebagaimana terdapat dalam studi-studi kelayakan tidak seharusnya diacu dalam perencanaan pembangunan industri perikanan. 


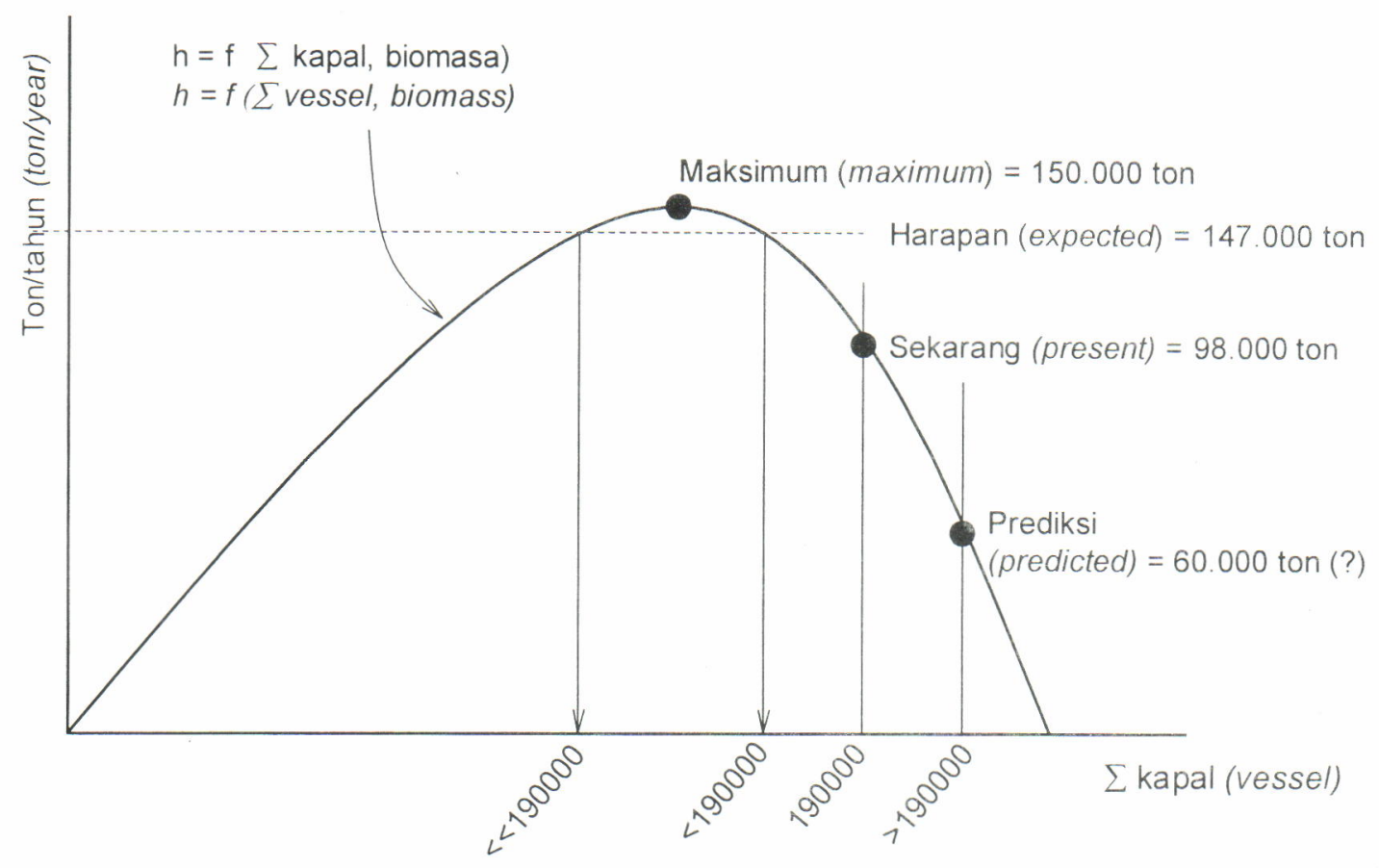

Gambar 6. Ilustrasi hubungan antara tingkat eksploitasi dengan panen lestari

Figure 6. Illustrative relationship between exploitation rate and sustainable harvest

Catatan/Note: Nelayan menangkap di Laut Jawa, Selat Makasar dan Laut Flores (potensi: 1.126.000 ton/tahun) dan nelayan WPU III memperoleh "share" 20\%, MSY optimis untuk WPU III $=150.000$ ton/Fishermen catch fish in the Java Sea, Makassar Strait, and Flores Sea (potential of 1,126,000 ton/year) and WPU III fishermen obtain a share of 20\%, MSY is optimistic for WPU III = 150,000 tons

Sebaliknya, gambar ilustratif di atas justru menunjukkan pentingnya pengurangan jumlah kapal penangkap untuk membuka kemungkinan peningkapan produksi (hasil tangkapan). Mengingat bahwa daerah penangkapan (fishing ground) dari armada kapal dari masing-masing kabupaten dalam penelitian ini pada umumnya sama, maka usaha peningkatan produksi melalui pengurangan jumlah kapal penangkap ini harus dilakukan secara secara terpadu, karena apabila tidak maka ada kemungkinan bahwa sebagian armada melakukan penurunan usaha sedangkan daerah lain melakukan hal yang sebaliknya

Dilihat dari beberapa sisi, terutama sosial dan politik, masalah rasionalisasi ini merupakan hal yang sangat sensitif. Sebagaimana tercermin dari hasil pertemuan konsultatif di depan stakeholders dalam rangka penelitian ini, gagasan rasionalisasi merupakan gagasan yang tidak populer. Pengurangan jumlah armada penangkap (atau penurunan efektivitas tangkap) sering dianggap sebagai kebijakan mundur karena mudah diartikan sebagai pengurangan kesempatan berusaha bagi sebagian individu dan mempertahankan kesempatan bagi individu lainnya. Dalam hal ini, salah satu alternatif pemecahan yang dapat dipertimbangkan penerapannya adalah bahwa penurunan total upaya yang dilakukan harus berlaku adil untuk semua, misalnya dihitung berdasarkan pembatasan tertentu yang diberlakukan untuk setiap kapal, misalnya melalui pemberlakuan pembatasan ukuran mata jaring untuk semua kapal, dan sebagainya (pembatasan input). Pembatasan yang merata ini juga dapat dilakukan dalam bentuk pembatasan output, misalnya melalui pembatasan kuota $^{3}$; akan tetapi hal ini barangkali akan tidak mudah diterapkan karena agak sulit diterima akal oleh nelayan untuk menghentikan kegiatan penangkapan pada saat mereka mendapatkan ikan yang masih

3 Pembatasan tangkapan sebesar 20 ton per kapal sempat disinggung dalam salah satu studi kelayakan pengembangan PPI (Anonim, 1992)/The limitation for the biggest catch is 20 tons per vessel has been noted in a PPI feasibility study (Anonim. 1992) 
dapat ditangkap, karena pada umumnya kesempatan seperti itu tidak diperoleh dengan mudah, sehingga nelayan memamandang bahwa kesempatan seperti itu tidak dapat diabaikan begitu saja.

\section{Peluang Peningkatan Produksi Perikanan Darat}

Pada sisi perikanan darat, data yang ada menunjukkan adanya potensi peningkatan produksi ikan, yang dikaitkan dengan masih rendahnya produktivitas perairan di berbagai lokasi, sebagaimana terlihat pada Gambar 7. Gambar tersebut menunjukkan bahwa produktivitas perairan sungai, budidaya tawar dan tambak untuk masing-masing tempat (kabupaten) berbeda dengan kisaran yang cukup lebar. Ini berarti bahwa apabila faktor-faktor yang menjadi kendala ataupun hambatan dapat ditangani, produktivitas di beberapa tempat dapat ditingkatkan, sehingga total produksi secara keseluruan dari wilayah-wilayah tersebut dapat ditingkatkan.

Gambar 7 menunjukkan bahwa produktivitas sungai tertinggi ada di wilayah Jepara yaitu kurang lebih 5 ton/ha/tahun. Apabila diasumsikan bahwa angka ini dapat dijadikan sebagai acuan, maka produktivitas sungai di kabupaten-kabupaten lain masih dapat ditingkakan sebanyak lebih dari 4 ton/ha/tahun. Apabila asumsi yang sama dapat pula diterapkan untuk semua lokasi dimana produktivitas sumberdaya perikanan daratnya masih rendah, maka dapat diprediksikan terjadinya peningkatan produksi ikan sungai menjadi 7.500 ton/tahun (luas sungai di kabupaten lain=1.500 ha). Angka ini cukup fantastis, karena mendekati angka volume produksi tahunan untuk seluruh Propinsi Jawa Tengah

Terlepas dari presentasi dari gambaran positif di atas, berbagai aspek, misalnya aspek teknologi, aspek sosial dan sebagainya, harus dikaji lebih mendalam. Hal ini diperlukan terutama untuk mengukur besarnya kemungkinan keberhasilan dari realisasi dari potensi tersebut. Berdasarkan data yang dikumpulkan melalui kegiatan lapang dalam penelitian ini, permasalahan-permasalahan menonjol yang ada dalam pengembangan perikanan darat di lokasi penelitian ini adalah di antaranya: pengadaan bibit yang berkualitas, ketersediaan lahan dengan air yang cukup dan pakan

Bagi wilayah dalam cakupan penelitian ini, keterbatasan pasokan air yang diperlukan untuk pengembangan perikanan darat terkait dengan rendahnya curah hujan di wilayah-wilayah tersebut Dengan demikian, salah satu solusi yang dapat dipertimbangkan adalah mengoptimalkan keberadaan air langka tersebut, misalnya dengan mengintensifkan pembangunan infrastruktur perairan. Satu hal yang dapat dipandang sebagai faktor positif dalam kaitannya dengan masalah ini adalah bahwa di beberapa wilayah pengembangan infrastruktur telah diprogramkan dan bahkan diimplementasikan pelaksanaannya. Sebagai contoh adalah program pengairan di Blora, yang salah satu bentuknya adalah perbaikan bendungan dan saluran-saluran utama maupun saluran-saluran percabangannya melalui Proyek Jeratunseluna. Solusi

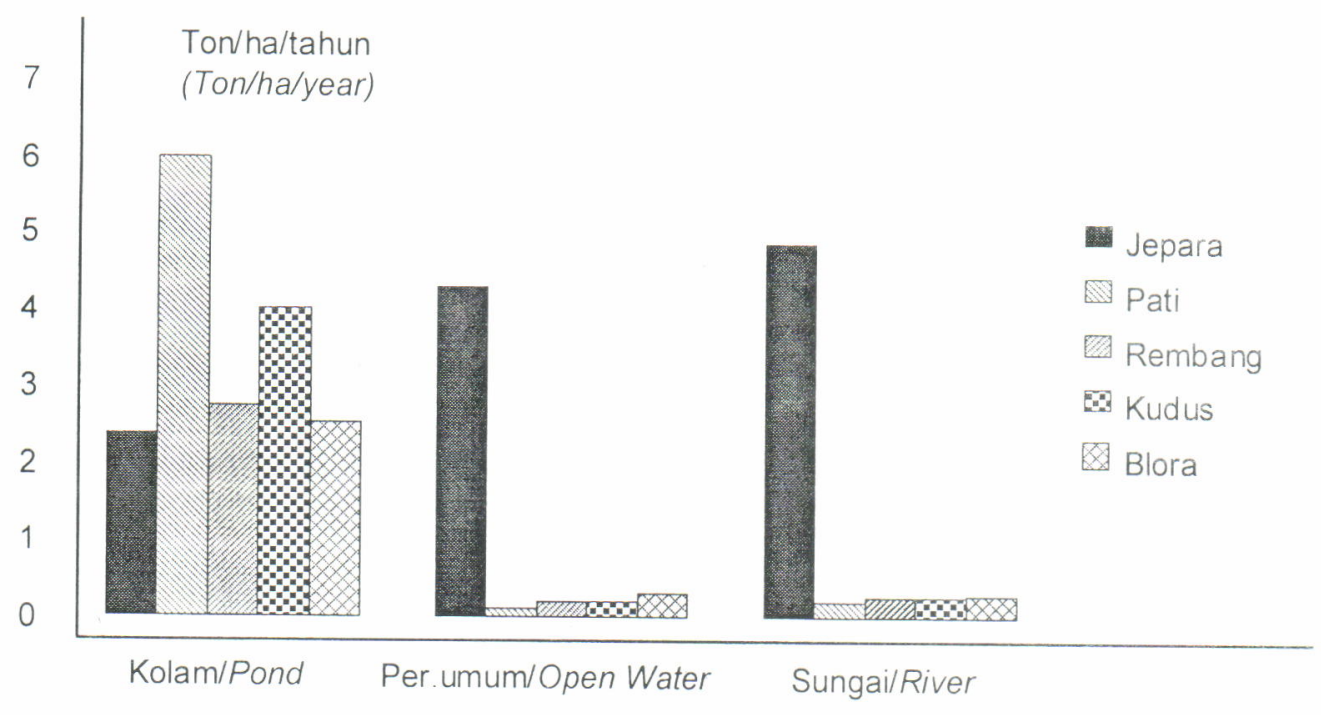

Gambar 7. Produktivitas lahan perikanan darat

Figure 7. Productivity of inland aquaculture 
lain yang dapat pula dilakukan untuk meningkatkan peluang pengembangan perikanan darat, terutama budidaya kolam, adalah melalui pembangunan sumursumur bor sedalam 40-60 meter sebagaimana telah dicoba di beberapa lokasi Kabupaten Blora. Sampai tingkat tertentu, kegiatan pembuatan sumur bor dapat dipertimbangkan untuk mengembangkan kegiatan budidaya. Hanya saja, kapasitas sumberdaya air yang memungkinkan dilakukannnya kegiatan pengeboran ini harus terlebih dahulu diketahui sehingga tidak terjadi dampak yang negatif pada sektor-sektor lain yang terkait.

Sebagai akibat dari keterbatasan ketersediaan air, pengadaan benih juga menjadi kendala dalam pengembangan budidaya di wilayah penelitian. Para petani ikan (pembudidaya) di beberapa kabupaten bahkan harus mengandalkan pasokan benih dari kabupaten di luar propinsi Jawa Tengah. Saat ini, usaha pembenihan yang dapat berjalan cukup baik dengan kualitas produk yang unggul dapat dijumpai di Kabupaten Kudus. Ini tidak lain karena ketersediaan air tawar bersih yang relatif lebih baik di kabupaten ini dibanding kabupaten-kabupaten di sekitarnya. Karenanya, para pembudidaya dari kabupatenkabupaten di sekitarnya pun banyak terbantu oleh usaha pembenihan di Kudus ini. Berlangsungnya kegiatan produksi di Kudus dan permintaan pasokan dari wilayah-wilayah di sekitarnya ini telah menyebabkan terbentuknya suatu sinergi positif karena potensi pasar lokal bibit ikan di Kudus sangat terbatas, sedang daerah lain memiliki peluang untuk melakukan pembesaran namun tidak dapat mengembangkan pembenihan sebaik pembenih di Kudus.

Masalah pakan juga menjadi tantangan yang cukup signifikan bagi sebagian pembudidaya. Beberapa daerah, seperti Pati, Rembang dan Demak memiliki keunggulan dalam hal pasokan pakan, terutama untuk budidaya lele. Hal ini terkait dengan adanya produksi ikan rucah yang cukup di lokasi-lokasi tersebut. Sementara itu, di daerah lain, harga pakan terlalu tinggi karena tidak adanya bahan baku seperti halnya di Pati, Rembang, dan Demak. Menyangkut hal ini, solusi yang dapat dipertimbangkan adalah di antaranya pengembangan secara terpadu antara peternakan dan perikanan (terutama lele). Observasi di lapangan menunjukkan bahwa usaha terpadu tersebut dimungkinkan, sebagaimana yang terjadi di salah satu lokasi penelitian, dimana limbah dari peternakan ayam dapat dimanfaatkan untuk mendukung pengadaan pakan untuk usaha budidaya lele. Seperti halnya hubungan antara pembenih dan pembudidaya pembesaran, hubungan antara pembudidaya lele dengan peternak pun menumbuhkan sinergi yang positif; peternak tidak perlu mengeluarkan ongkos untuk membuang limbahnya sedang pembudidaya dapat menekan biaya pakan karena limbah tersebut pada umumnya diperoleh secara cuma-cuma.

Terlepas dari berbagai bentuk kendala yang ada, usaha realokasi sumberdaya (fisik dan sosial) dari penangkapan laut ke budidaya atau penangkapan di perairan umum, sangat jelas akan menghasilkan margin manfaat yang positif. Ini terjadi karena pengurangan input yang terkait dengan usaha penangkapan justru berkecenderungan meningkatkan produksi (baik di darat maupun di laut). Lebih lanjut, penanaman input hasil rasionalisasi penangkapan, ke usaha perikanan di darat dapat dipastikan akan meningkatkan produksi. Dengan demikian, langkah tersebut dapat dikatakan sebagai suatu langkah yang bermanfaat ganda

Satu-satunya tindakan lain yang merupakan alternatif signifikan terhadap realokasi dari perikanan laut ke perikanan darat adalah ekspansi daerah penangkapan. Hanya saja, satu hal yang harus dipertimbangkan adalah bahwa biaya yang dikeluarkan untuk itu akan sangat besar, dengan demikian pilihan yang lebih efisien adalah realokasi ke perikanan darat. Untuk saat ini, ekspansi yang memiliki peluang besar adalah ke perairan-perairan di Indonesia Timur. Mengingat bahwa dana yang tersedia di kabupatenkabupaten pada umumnya tidak terlalu besar, ekspansi ke wilayah perairan laut yang jauh, besar kemungkinannya hanya akan dinikmati oleh sebagian kecil nelayan. Dengan demikian, dari sisi pemerataan, solusi semacam ini tidak baik

\section{Masalah Pemasaran dan Peluang Penggalian Potensi Pasar Lokal}

Apabila skenario peningkatan produksi dapat direalisasikan, baik melalui eksploitasi sumberdaya laut maupun darat, masalah yang kemudian menghadang pengembangan industri perikanan adalah masalah pemasaran. Sejauh ini, baik pengusaha besar maupun pengusaha kecil pada umumnya menghadapi permasalahan yang cukup berpengaruh pada prospek pemasaran produk perikanan dari wilayah-wilayah di lokasi penelitian. Tabel 2 menunjukkan analisis pasar untuk pengusaha berskala kecil dan besar.

Sejauh ini, perkembangan pemasaran produk perikanan oleh pengusaha kecil terutama terhambat oleh rendahnya mutu ikan dan panjangnya jarak antara lokasi pemasaran dan lokasi produksi. Dengan mutu yang masih tergolong rendah, pemasaran produk yang dihasilkan oleh pengusaha kecil hanya terbatas pada konsumen-konsumen kelas bawah, yang pada umumnya hanya mempertimbangkan atribu-atribut mutu primer dari produk yang dibelinya; atribut-atribut 
Tabel 2. Analisis pasar pengusaha kecil dan pengusaha besar, berdasar data tahun 1997-2001

Table 2. Market analyses for small-scale and large-scale entrepreneurs, based on 1997-2001

\begin{tabular}{|c|c|c|}
\hline & Pengusaha Kecil/Small Scale & Pengusaha Besar/Large Scale \\
\hline $\begin{array}{l}\text { Karakteristik sasaran/ } \\
\text { Target characteristics }\end{array}$ & $\begin{array}{l}\text { Konsumen langsung/direct } \\
\text { consumers } \\
\text { Middlemen dalam kabupaten } \\
\text { /wilayah terbatas (local } \\
\text { middlemen) }\end{array}$ & $\begin{array}{l}\text { - Middlemen luar } \\
\text { kabupaten/middlemen outside } \\
\text { district } \\
\text { Importir di Luar Negeri/foreign } \\
\text { importers }\end{array}$ \\
\hline Ukuran pasar/Market size & $\begin{array}{l}\text { - Terbatas pada kebutuhan pasar } \\
\text { lokal/limited to local market }\end{array}$ & $\begin{array}{l}\text { - Mencakup sebagian kebutuhan } \\
\text { pasar lokal dan pasar regional, } \\
\text { mancanegara/local and int. } \\
\text { market }\end{array}$ \\
\hline $\begin{array}{l}\text { Perkembangan } \\
\text { pasar/Market development }\end{array}$ & - Mandek/Stagnant & $\begin{array}{l}\text { Mendekati mandek/almost } \\
\text { stagnant }\end{array}$ \\
\hline $\begin{array}{l}\text { Penguasaan sasaran/ } \\
\text { Target control mechanism }\end{array}$ & Mutual understanding & Quality assurance \\
\hline $\begin{array}{l}\text { Media komunikasil } \\
\text { Communication media }\end{array}$ & $\begin{array}{l}\text { - Kontak langsung, telepon/direct } \\
\text { contact, phone }\end{array}$ & $\begin{array}{l}\text { Kontak langsung, telepon, } \\
\text { internet/direct contact, phone, } \\
\text { internet }\end{array}$ \\
\hline $\begin{array}{l}\text { Kekuatan } \\
\text { kompetisi/Competition } \\
\text { strength }\end{array}$ & $\begin{array}{l}\text { - Tidak ada kekuatan andalan/no } \\
\text { prime strength }\end{array}$ & $\begin{array}{l}\text { - Spesialisasui produk/Product } \\
\text { specialty }\end{array}$ \\
\hline $\begin{array}{l}\text { Hambatan } \\
\text { pemasaran/Marketing } \\
\text { barrier }\end{array}$ & $\begin{array}{l}\text { - Mutu dan jarak/quality and } \\
\text { distance }\end{array}$ & $\begin{array}{l}\text { Penguasaan permainan dagang } \\
\text { di luar negeri/lnternational } \\
\text { market control }\end{array}$ \\
\hline
\end{tabular}

sekunder, seperti estetika, nilai nutrisi, maupun palatabilitas cenderung diabaikan.

Bagi produsen skala kecil yang mampu menghasilkan produk berkualitas baik, hambatan selanjutnya dalam pemasaran antara lain adalah volume dan fluktuasi produksi. Dengan kondisi seperti itu, faktor economies of scale menjadi relevan, satu hal yang pada gilirannya menyebabkan sulitnya pengusaha berskala kecil untuk melakukan pengiriman barang. Pengusaha besar, di sisi lain, dapat melakukan pengiriman barang pada lokasi-lokasi yang jauh karena volume produksi tinggi dan fluktuasinya rendah. Berdasarkan observasi lapang, salah satu solusi pemecahan masalahnya adalah (1) mengintegrasikan usaha skala kecil dalam kedalam sistem usaha pengusaha besar dan (2) mengorganisir pengusaha berskala kecil untuk memungkinkan peningkatan efisiensi sehingga dapat melakukan pengembangan usaha dengan lebih baik. Salah satu contoh pengintegrasian usaha skala kecil, khususnya pada aspek pemasaran, kedalam sistem usaha pengusaha besar adalah melalui kegiatan pemasaran bersama. Istilah 'nitip dagangan' adalah salah satu contoh bentuk pengintegrasian dimaksud, yang telah dirintis oleh para pengusaha skala kecil. Pengusaha kecil yang bermaksud mengirimkan produknya ke luar kota dapat mengoptimalkan ruang pada sarana pengangkutan yang dimiliki oleh pengusaha besar. Dengan cara itu, produk yang dikirim dapat menjangkau sasaran yang lebih jauh dan, di sisilain, jaminan yang diberikan oleh pengusaha besar dapat dimanfaatkan untuk meyakinkan pedagang yang menerima pasokan produk. Sementara itu, alternatif kedua dimaksudkan untuk mensiasati economies of scale, sehingga biaya-biaya yang berhubungan dengan produksi dan pemasaran dapat diperkecil sehingga profit positif dapat direalisasikan.

Sementara itu, bagi pengusaha besar, yang beberapa di antaranya telah melakukan kegiatan ekspor, masalah yang sering menjadi hambatan dalam pengembangan pasar adalah menyangkut permainan dagang di luar negeri. Sebagai ilustrasi, salah satu hasil wawancara dengan pengusaha ikan berskala besar di Kabupaten Rembang, menunjukkan bahwa mitra dagang di luar negeri sering mempermainkan eksportir Indonesia dengan berbagai dalih; diungkapkan berdasarkan dari pengalaman pemasaran ikan asin ke Srilangka, misalnya, importir 
di negara tujuan, memanfaatkan kelemahan penguasaan sistem pemasaran internasional para eksportir Indonesia, sering berusaha mencari berbagai alasan untuk menunda pembayaran. Pengalaman negatif yang terkait dengan kekurangan-kekurangan yang ada pada para eksportir Indonesia tersebut telah menjadi salah satu penyebab kemandegan kegiatan ekspor dari sebagian pengusaha.

Dalam bahasan pada bagian ini, satu hal yang juga perlu diperhatikan adalah tentang perlunya perbaikan mutu produk secara umum, baik untuk pengusaha besar maupun untuk pengusaha berskala kecil. Ini menyangkut tidak hanya produk-produk segar, melainkan juga untuk peroduk-produk olahan. Data yang berhasil dikumpulkan (seperti telah pula disinggung sebelumnya), salah satu kendala pengembangan pasar adalah masalah mutu. Masalah mutu ini terkait dengan faktor-faktor yang mempengaruhi sisi produksi, misalnya ketersediaan teknologi, tersedianya sarana, tersedianya dukungan finansial, kelembagaan, dan sebagainya. Disamping itu, sebagaimana disebutkan pada alinea di atas, sisi pengembangan budaya mengkonsumsi ikan berkualitas baik di kalangan masyarakat.

\section{Penggalian Potensi Pasar Lokal}

Tanpa harus diartikan mengabaikan usaha pengembangan pasar di luar wilayah atau pasar mancanegara, mengingat berbagai kesulitan yang dihadapi dalam pemasaran ke luar wilayah, salah satu cara untuk memperkuat dan mengembangkan industri perikanan adalah melalui penggalian pasar lokal. Ini menjadi semakin relevan mengingat bahwa diskusi di atas cenderung mengarahkan realokasi dana dari program pegembangan industri penangkapan laut ke perikanan darat, yang pada akhirnya akan berujung pada peningkatan volume produksi ikan secara keseluruhan. Pasar lokal yang dimaksud dalam konteks diskusi ini adalah konsumen dari kalangan penduduk di sekitar wilayah dimana produksi berlangsung. Salah satu peluang untuk mengembangkan pasar lokal adalah dengan merealisasikan potensi yang ada di kalangan masyarakat. Apabila dibandingkan dengan sasaran

Tabel 3. Konsumsi ikan di Wilayah Pengembangan Utama (WPU) III Tahun 2001

Table 3. Fish consumption at "Wilayah Pengembangan Utama" (WPU) III, Year 2001

\begin{tabular}{lc}
\hline Kabupaten/District & $\begin{array}{c}\text { Konsumsi perkapita } \\
\text { (Kg/Kapita/Tahun)/ } \\
\text { Per-capita consumption } \\
\text { (kg/capita/year) }\end{array}$ \\
\hline Rembang & 11.60 \\
Jepara & 11.90 \\
Pati & 21.98 \\
Blora & 10.30 \\
Kudus & 11.50 \\
Demak & 10.30 \\
\hline
\end{tabular}

konsumen juga sangat berpengaruh. Dengan demikian perbaikan-perbaikan yang dilakukan tidak hanya menyangkut pengembangan akses teknologi, penyediaan sumber dana, dan perbaikan kelembagaan, tapi juga menyangkut peningkatan apresiasi masyarakat terhadap ikan dengan segenap atribut mutu yang terkait dengannya. Untuk itu, salah satu pos pembelanjaan yang perlu dipertimbangkan dalam rangka penggunaan dana realokasi, sebagaimana diusulkan dalam laporan ini pada diskusi pada bagian depan dari laporan ini, yang menyangkut tingkat konsumsi ikan perkapita masyarakat Indonesia yang akan dicapai pada tahun 2005 sebesar 25 $\mathrm{kg} / \mathrm{kapita/tahun,} \mathrm{maka} \mathrm{terdapat} \mathrm{selisih} \mathrm{yang} \mathrm{cukup}$ besar antara angka sasaran tersebut dengan angka konsumsi untuk masing-masing kabupaten di lokasi penelitian

Tabel 3 merupakan statistik perikanan yang merepresentasikan konsumsi ikan perkapita pertahun di masing-masing kabupaten di lokasi penelitian ${ }^{4}$. Selisih antara angka-angka pata Tabel 3 dengan target konsumsi $25 \mathrm{~kg} / \mathrm{kapita/tahun} \mathrm{pada} \mathrm{kabupaten-}$ 


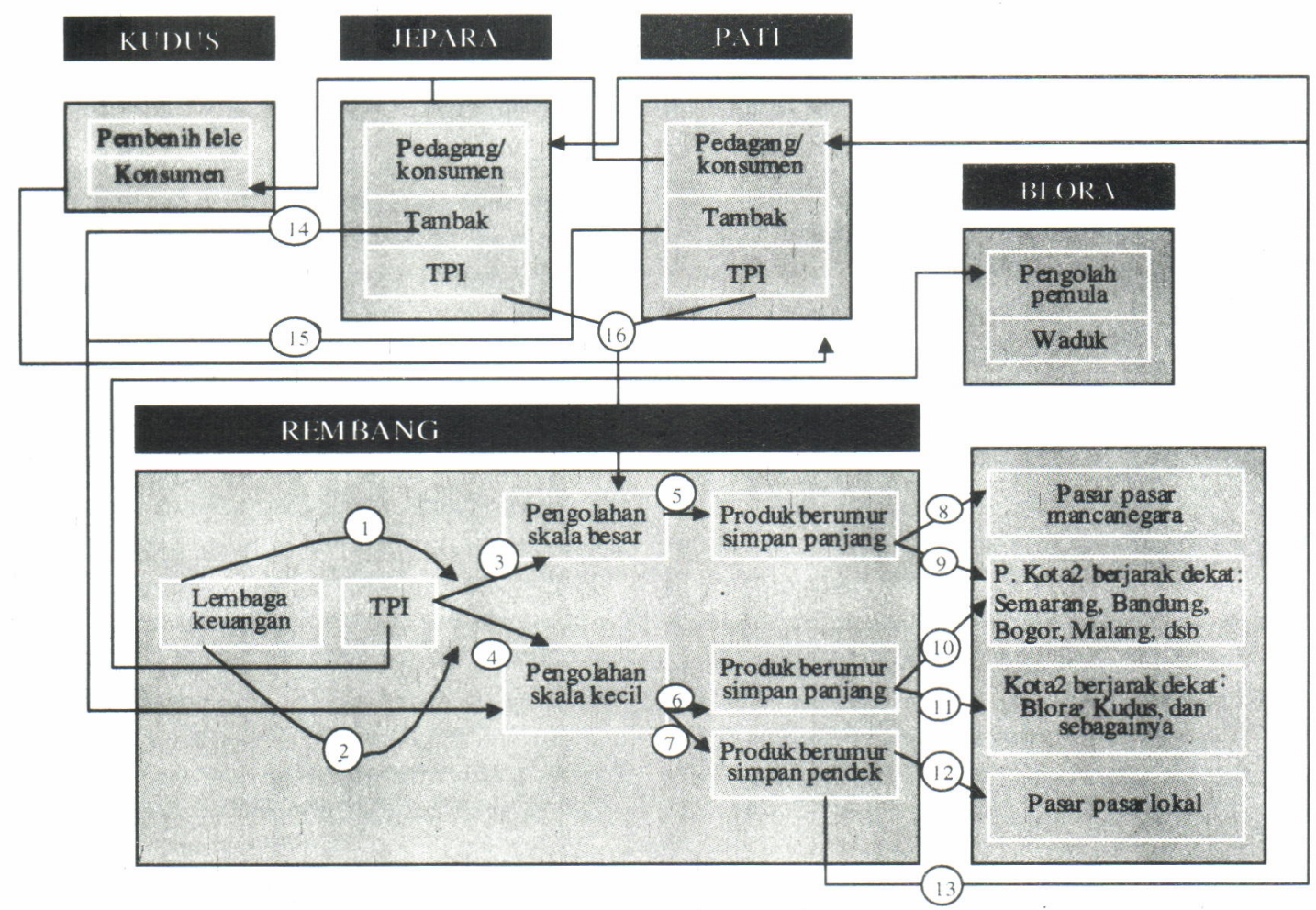

Gambar 8. Ilustrasi interaksi industrial di lokasi penelitian

Figure 8. Illustration for the industrial interaction in the research location

Catatan/Note: (Ikhtisar permasalahan yang teridentifikasi) :

1. Sebagian pengolah/pengumpul skala besar berkecenderungan untuk menunda pembayaran pembelian ikan sehingga likuiditas TPI menjadi terganggu. Ada indikasi bahwa kecenderungan ini lebih besar pada nelayan lokal dibanding pada nelayan dari daerah lain/Most of the big-scale broker/processing have a tendency to delay payment of buying fish until liquidation of TPI becomes inconvenient. There is indication that this practice is more likely to be found in local fishermen than by fishermen from other areas;

2. Pengolahan berskala kecil tidak mudah untuk mendapatkan kredit usaha karena ketiadaan agunan yang cukup untuk memanfaatkan fasilitas pinjaman dari lembaga perbankan/The small-scale processor does not obtain business credit easily as there is a lack collateral that is enough to use the loaning facilities from the bank;

3. Pasokan ikan tidak mencukupi sehingga sebagian kebutuhan harus didatangkan dari luar wilayah/The fish supply is insufficient that part of raw material must come from another area;

4. Pasokan ikan berfluktuasi karena musim/The fish supply is not fluctuating because of season;

5. Tidak ada masalah signifikan/Not significant problem

6. Teknologi, modal dan jaringan pemasaran terbatas; dengan keterbatasan itu, mereka sering tidak berdaya saat terjadi praktek perang harga yang dilakukan oleh pengusaha besar/Technology, capital, and marketing network are limited; due to these limitations, they feel powerless to the point that they must confront the huge business to a price competition,

Tidak ada permasalahan yang signifikan/Not significant problem

Sebagian pengusaha besar tidak menguasai sistem pemasaran internasional/Most big businesses do not corner the international market system;

9. Hanya sebagian pengusaha besar yang terkait dengan jaringan pemasaran yang kuat/Only a few of the big businesses that are involved in strong network marketing;

10. Untuk mengurangi ongkos transportasi dan untuk menembus pasar yang lebih jauh, pengolah kecil dapat menitipkan produknya kepada pedagang besar, tetapi ini tidak dilakukan setiap saat karena pengusaha besar akan meprioritaskan produknya/ln order to cut transportation costs and to break into a market located further away, the small process business deposits their product to the big dealer, but this does not happen often as the big business always prioritizes their product; 
11-13. Pasar hanya terbatas pada langganan yang telah ada dan tidak dapat dikembangkan karena masingmasing langganan telah terikat komitmen dengan pengolah (kelompok pengolah) lain/The market is limited to the available client and cannot be developed due to each client tied to a commitment to another processor (or group of processor);

14-15. Pasokan menurun karena ongkos produksi terlalu tinggi bagi sebagian besar petambak/Supply goes down due to high production costs for most brackish water farmer,

16. Penundaan pembayaran KLPI menyebabkan likuiditas TPI menjadi terganggu/Delay in KLPI payment causes TPI liquidation become a problem.

kabupaten di wilayah penelitian berkisar antara 10-13 $\mathrm{kg} / \mathrm{kapita/tahun.} \mathrm{Apabila} \mathrm{angka-angka} \mathrm{ini} \mathrm{dikalikan}$ dengan jumlah penduduk pada masing-masing kabupaten tersebut, diperoleh kekurangan konsumsi sebesar 52 juta kg/tahun. Angka ini merupakan potensi yang dapat dijadikan salah satu sasaran bagi para pengusaha di wilayah penelitian dalam pengembangan pasarnya. Dari hasil wawancara dengan nara sumber dan observasi di lapangan, diperoleh bahwa tantangan terberat dalam merealisasikan potensi pasar tersebut adalah budaya makan ikan, yang pada sebagian wilayah penelitian ini masih tergolong rendah. Disamping itu, diperoleh pula fakta-fakta yang menunjukkan bahwa perubahan kondisi sosial masyarakat akhir-akhir ini, terutama sejak terjadinya krisis ekonomi yang berkepanjangan, telah menyebabkan perubahan pada pola konsumsi. Sebagian konsumen ikan mengalihkan pembelanjaan pada produk-produk substitusi dengan harga yang lebih terjangkau. Berdasarkan itu, salah satu yang dapat disimpulkan dari penelitian ini adalah perlunya pengkajian yang lebih mendalam mengenai aspek sosial dan budaya yang berpengaruh pada pola konsumsi di wilayah-wilayah ini.

\section{Keterkaitan antar komponen sistem dalam industri perikanan}

Sebagaimana terjadi pula di berbagai wilayah lain, berbagai komponen sistem dalam industri perikanan di lokasi penelitian saling terkait satu sama lain membentuk jejaring yang saling mendukung dan membutuhkan satu sama lain. Gambar 8 mengilustrasikan keterkaitan tersebut. Ditunjukkan dalam gambar tersebut (dan telah disinggung pada bahasan mengenai pengembangan budidaya perikanan darat), misalnya, bahwa meskipun Kudus merupakan lokasi pembenihan lele berkualitas baik yang cukup produktif, pemasaran benih lele yang diproduksi oleh para pembenih di wilayah tersebut sebagian besar harus dilakukan ke luar daerah karena terbatasnya lahan pembesaran lele di Kudus. Sebaliknya, beberapa wilayah sekitar, termasuk beberapa kecamatan di Pati, Demak, dan Rembang menggantungkan pasokan benih lele dari Kudus, yang dikenal berkualitas baik. Tingginya kualitas benih lele di Kudus terkait dengan ketersediaan air tawar berkualitas baik di wilayah tersebut. Sementara itu, wilayah sekitar memiliki keunggulan dalam hal ketersediaan lahan untuk pengusahaan kolam budidaya lele dan ikan air tawar lainnya. Pada gilirannya, sejumlah besar ikan lele hasil pembesaran wilayah sekitar tersebut dipasarkan kembali ke Kudus, karena kebutuhan pasokan ikan yang besar di Kudus. Gambaran tentang interaksi-interaksi lain dapat diikuti pada Gambar 8

Hasil penelitian ini, sebagaimana telah pula diungkap sebagian pada bagian terdahulu, menunjukkan adanya berbagai permasalahan yang terkait dengan jaringan industrial, termasuk masalah jaringan pemasaran, persaingan, dan permodalan. Informasi yang diperoleh dari wawancara dengan stakeholders menunjukkan bahwa permasalahanpermasalahan tersebut berkembang menjadi lebih signifikan seiring dengan menurunnya produktivitas penangkapan laut. Kecenderungan penundaan pembayaran KPLI, ketidakpercayaan perbankan untuk memberikan kredit perikanan, dan kesulitan pasokan bahan baku merupakan beberapa permasalahan dimaksud, yang terkait langsung dengan penurunan produktivitas perairan laut.

Lepas dari permasalahan-permasalahan itu, sisi positif dari keberadaan jejaring industri tersebut adalah bahwa pengembangan industri atau agribisnis perikanan terpadu di wilayah tersebut dapat memanfaatkannya. Rentang waktu yang telah berlalu sepanjang keberadaan jejaring tersebut merupakan suatu bukti ketahanan dari sistem yang terbangun secara alami. Dengan demikian, perbaikan-perbaikan hanya diperlukan untuk makin memperkuat sisi-sisi yang dianggap lemah sehingga dapat diharapkan bahwa embrio yang diperbaiki tersebut berkembang menjadi model pengembangan industri yang diharapkan dapat kinerja lebih baik. Dalam hal ini, sebagaimana konsep agribisnis yang diacu dalam penelitian ini, perbaikan tersebut mencakup rantairantai yang menghubungkan antara simpul (komponen dalam sistim) industri, mulai dari hulu sampai bagian hilirnya.

Berdasarkan analisis di atas, maka model pengembangan industri perikanan di lokasi penelitian dapat dilakukan berdasarkan alur pikir sebagai berikut 
1. Karena upaya penangkapan ikan di laut tidak dapat ditingkatkan lebih jauh tanpa adanya ekspansi ke wilayah perikanan di propinsi lain yang jauh dari tempat-tempat pendaratan di kabupaten-kabupaten dalam wilayah penelitian, sedangkan produktivitas perikanan darat masih menunjukkan peluang pengembangannya, maka pilihan yang lebih baik untuk meningkatkan produksi ikan di wilayah tersebut adalah melalui pemberian bobot yang lebih pada usaha perikanan darat

2. Karena peningkatan produksi akan menimbulkan tantangan baru, yaitu dalam hal pemasaran, sedangkan di dalam wilayah terdapat potensi pasar yang belum tergali secara optimal, maka penggalian potensi pasar lokal ini harus menjadi salah satu prioritas dalam pengembangan industri perikanan secara keseluruhan; apalagi mengingat bahwa penggalian potensi pasar lokal tersebut akan berdampak positif pula pada pencapaian salah satu program Departemen Kelautan dan Perikanan yaitu peningkatan konsumsi ikan perkapita sebesar $25 \mathrm{~kg} /$ tahun.

3. Karena data di lapangan menunjukkan bahwa pengembangan pasar selama ini terkendala di sisi produsen oleh rendahnya mutu produk dan di sisi konsumen oleh faktor sosial dan budaya, maka pendekatan perbaikan sisi pasca panen produk, serta sosial dan budaya konsumen dapat dijadikan salah satu strategi dalam pengembangan pasar

4. Karena economies of scale merupakan faktor yang cukup berpengaruh terhadap usaha ekspansi pemasaran oleh pengusaha kecil ke tujuan yang jauh, maka kerjasama antar pengusaha kecil dan atau kemitraan antara pengusaha kecil dengan pengusaha besar perlu pula diusahakan.

5. Bahwa masing-masing komponen dalam sistem industri dalam satu kabupaten maupun antar kabupaten berpeluang meningkatkan kinerjanya (misal:Meningkatkan efisiensi dan meningkatkan kekuatan pasar) melalui suatu kerjasama, maka model pengembangan terpadu di dalam suatu wilayah yang mencakup berbagai kegiatan industri perikanan di beberapa kabupaten perlu dipertimbangkan.

6. Bahwa selama ini telah terbentuk jejaring yang bertahan secara alamiah, maka model pengembangan industri secara terpada dapat dilakukan dengan cara mengoptimalkan keberadaan jejaring, yaitu memperbaiki
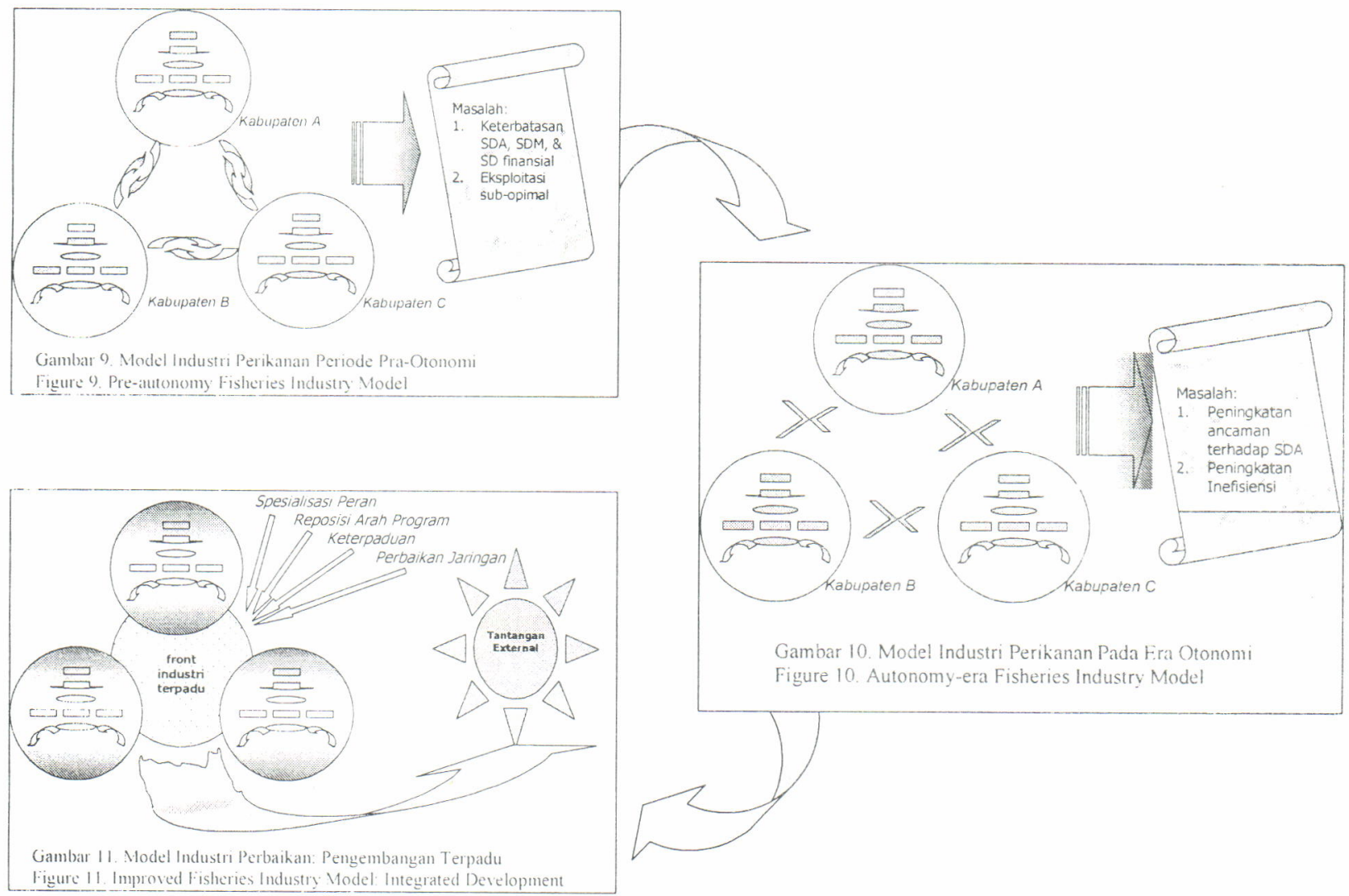

inure 11. Improved Fishcries Industry Model: Integrated Developmen 
Tabel 4. Nilai beberapa kriteria kinerja subsistem industri perikanan

Table 4. Values of performance criteria of fisheries industry sub-systems

\begin{tabular}{|c|c|c|c|c|c|}
\hline & Jepara & Pati & Rembang & Kudus & Blora \\
\hline \multicolumn{6}{|c|}{ Industri Penangkapan Ikan Laut/Marine Capture Fishery } \\
\hline Nilai produksi/Value (Rp) & $\begin{array}{l}5.3 \text { milyarl } \\
\text { billion }\end{array}$ & $\begin{array}{l}120 \text { milyarl } \\
\text { billion }\end{array}$ & $\begin{array}{l}110 \text { milyarl } \\
\text { billion }\end{array}$ & - & - \\
\hline Kontinuitas/Continuity & Rendah/low & $\begin{array}{l}\text { agak rendah/ } \\
\text { slightly low }\end{array}$ & $\begin{array}{l}\text { agak rendah/ } \\
\text { slightly low }\end{array}$ & - & - \\
\hline $\begin{array}{l}\text { Standar deviasi Produksi triwulan/ } \\
\text { Std. deviation of three-monthly prod }\end{array}$ & $53.9 \%$ & $38.8 \%$ & $36.0 \%$ & - & - \\
\hline Jumlah nelayan/no. of fisher & 8.500 & 10.000 & 11.000 & - & - \\
\hline
\end{tabular}

Pembudidayaan Udang Tambak/Brackish Water Shrimp Culture

\begin{tabular}{|c|c|c|c|c|c|}
\hline Nilai produksi/Production value (Rp) & $\begin{array}{l}33 \text { milyarl } \\
\text { billion }\end{array}$ & $\begin{array}{l}190 \text { milyarl } \\
\text { billion }\end{array}$ & $\begin{array}{l}27 \text { milyarl } \\
\text { billion }\end{array}$ & - & - \\
\hline Kontinuitas/Continuity & Rendah/low & Rendah/low & Rendah/low & - & - \\
\hline $\begin{array}{l}\text { Standar deviasi Produksi triwulan/ } \\
\text { Std. deviation of three-monthly prod (\%) }\end{array}$ & 21.7 & 33.7 & 14.9 & - & - \\
\hline Jumlah petambak /no. of farmers & 3.600 & 20.600 & 2.900 & - & - \\
\hline \multicolumn{6}{|c|}{ Industri Pembudidayaan Kolam Ikan/Pond Culture } \\
\hline Nilai produksi/Production value $(\mathrm{Rp})$ & $\begin{array}{l}1.3 \text { jutal } \\
\text { million }\end{array}$ & $\begin{array}{l}8 \text { juta/ } \\
\text { million }\end{array}$ & $\begin{array}{l}0.4 \text { jutal } \\
\text { million }\end{array}$ & $\begin{array}{l}2 \text { jutal } \\
\text { million }\end{array}$ & $\begin{array}{l}1.7 \text { jutal } \\
\text { million }\end{array}$ \\
\hline Kontinuitas/Continuity & $\begin{array}{l}\text { Sedang/ } \\
\text { moderate }\end{array}$ & $\begin{array}{l}\text { Sedang/ } \\
\text { moderate }\end{array}$ & $\begin{array}{l}\text { Sedang/ } \\
\text { moderate }\end{array}$ & $\begin{array}{l}\text { Sedang/ } \\
\text { moderate }\end{array}$ & $\begin{array}{l}\text { Sedang/ } \\
\text { moderate }\end{array}$ \\
\hline $\begin{array}{l}\text { Standar deviasi Produksi triwulan/ } \\
\text { Std. deviation of three-monthly prod (\%) }\end{array}$ & 28.6 & 12.8 & 20.0 & 70.7 & 29.6 \\
\hline Jumlah pembudidaya/no. of fish farmer & 100 & 3.000 & 300 & 1.500 & 1.300 \\
\hline \multicolumn{6}{|c|}{ Industri Penangkapan Ikan Sungai/River Capture Fishing Industry } \\
\hline Nilai produksi/Production value (Rp) & $\begin{array}{l}4.0 \text { jutal } \\
\text { million }\end{array}$ & $\begin{array}{l}13.5 \text { jutal } \\
\text { million }\end{array}$ & $\begin{array}{l}1.4 \text { jutal } \\
\text { million }\end{array}$ & $\begin{array}{l}1.6 \text { jutal } \\
\text { million }\end{array}$ & $\begin{array}{l}15.0 \text { jutal } \\
\text { million }\end{array}$ \\
\hline Kontinuitas/Continuity & $\begin{array}{l}\text { Sedang/ } \\
\text { moderate }\end{array}$ & $\begin{array}{l}\text { Sedang/ } \\
\text { moderate }\end{array}$ & $\begin{array}{l}\text { Sedang/ } \\
\text { moderate }\end{array}$ & $\begin{array}{l}\text { Sedang/ } \\
\text { moderate }\end{array}$ & $\begin{array}{l}\text { Sedang/ } \\
\text { moderate }\end{array}$ \\
\hline $\begin{array}{l}\text { Standar deviasi Produksi triwulan/ } \\
\text { Std. deviation of three-monthly prod (\%) }\end{array}$ & 13.7 & 12.6 & 14.3 & 15.1 & 26.0 \\
\hline Jumlah nelayan/no. of fisher & 3.500 & 2.400 & 880 & 1.000 & 8.400 \\
\hline
\end{tabular}

Keterangan/Note:

1. Nilai produksi dari masing-masing kelompok jenis industri perikanan, digunakan sebagai proksi bagi besarnya manfaat dari beroperasinya masing-masing jenis industri tersebut/The values from each group of fishing industry are used as a proxy in how much utilization from each operation of every type of industry:

2. Nilai kontinuitas diberikan oleh stakeholders, yang mendasarkan penilaiannya pada kecenderungan produksi dari tahun ke tahun dan faktor-faktor yang mempengaruhinya/The continuity value is given by the stakeholders, which is based on yearly production productivities, and other contributing factors

3. Standar deviasi dari rata-rata produksi triwulan dipergunakan untuk memperoleh proksi bagi nila stabilitas (standar deviasi yang tinggi diasosiasikan dengan produksi yang tidak stabil)/Standard deviations obtained from quartely production averages is used in obtaining proxy for the stability value (the highest standard deviation is associated with an unstable production);

4. Penyerapan tenaga kerja dipergunakan sebagai proksi 'pemerataan'/Absorption of labor is used as proxy for equity. 
A. H. Purnomo, S. H. Suryawati, Y. Hikmayani dan E. Reswati

Tabel 5. Skor beberapa kriteria kinerja subsistem industri perikanan

Table 5. Scores of performance criteria of fishories industry sub-systems

\begin{tabular}{lrrrrr}
\hline & Jepara & Pati & Rembang & Kudus & Blora \\
\hline \multicolumn{4}{c}{ Industri Penangkapan Ikan Laut/Marine } & Capture Fishery & \\
\hline Nilai manfaat/Benefit & 4.4 & 100.0 & 91.7 & - \\
Kontinuitas/Continuity & 30.0 & 40.0 & 40.0 & - \\
Stabilitas/Stability & 0.0 & 22.4 & 28.0 & - & - \\
Ekuitabilitas/Equitability & 77.3 & 91.0 & 100 & - \\
Total & 91.7 & 252.4 & 259.7 & - \\
\hline
\end{tabular}

Pembudidayaan Udang Tambak/Brackish Water Shrimp Culture

\begin{tabular}{lrrrrr}
\hline Nilai manfaat/Benefit & 17.4 & 100 & 14.2 & - & - \\
Kontinuitas/Continuity & 30.0 & 30.0 & 30.0 & - & - \\
Stabilitas/Stability & 56.6 & 32.6 & 80.0 & - & - \\
Ekuitabilitas/Equitability & 17.5 & 100 & 14.0 & - & - \\
Total & 121.5 & 262.6 & 138.2 & - & - \\
\hline \multicolumn{5}{c}{ Industri Pembudidayaan Kolam Ikan/Pond Culture } \\
\hline Nilai manfaat/Benefit & 16.5 & 100 & 5.0 & 25.0 & 50.0 \\
Kontinuitas/Continuity & 50.0 & 50.0 & 50.0 & 50.0 & 40.2 \\
Stabilitas/Stability & 42.8 & 74.2 & 60.0 & 0.0 & 13. \\
Ekuitabilitas/Equitability & 33.3 & 100 & 10.0 & 15.0 & 124.5 \\
Total & 142.6 & 324.2 & 125.0 & 70 &
\end{tabular}

Industri Penangkapan Ikan SungailRiver Capture Fishing Industry

\begin{tabular}{lrrrrr}
\hline Nilai manfaat/Benefit & 26.7 & 90 & 10.7 & 12.7 & 100.0 \\
Nilai manfaat/Benefit & 50.0 & 50.0 & 50.0 & 50.0 & 50.0 \\
Kontinuitas/Continuity & 72.6 & 74.8 & 71.4 & 69.8 & 48.0 \\
Stabilitas/Stability & 41.7 & 28.6 & 10.5 & 11.9 & 100.0 \\
Ekuitabilitas/Equitability & 191.0 & 243.4 & 142.6 & 144.4 & 298.0 \\
\hline
\end{tabular}

Industri Pengolahan Ikan/Fish Processing Industry

\begin{tabular}{lrrrrr}
\hline Bahan Baku/Raw material & 1 & 10 & 9 & 2 & 9 \\
Penduduk/Population & 3 & 2 & 2 & 2 & 4 \\
Industri/Industry & 4 & 10 & 8 & 10 & 4 \\
Listrik/Electricity & 3 & 3 & 1 & 3 & 1 \\
Air/Water & 3 & 4 & 4 & 3 & 3 \\
Bank & 3 & 3 & 2 & 4 & 2 \\
KBU/Telephone booth & 7 & 9 & 5 & 9 & 5 \\
Total & 24 & 42 & 31 & 29 & 28 \\
\hline
\end{tabular}

Keterangan/Note:

1. Skor pada masing-masing kolom pada Tabel 5. merupakan hasil standarisasi nilai-nilai pada Tabel 4, yang memungkinkan penyeragaman unit, yang memungkinkan penjumlahan nilai dari kriteria-kriteria yang berbeda/ The scores from each column in Table 5 consists of standrization results on Table 4, which enables for unit uniformity, which enables for the amount of values from different criteria.

2. Karena adanya perbedaan karakteristik yang khusus, pemeranan untuk industri pengolahan dilakukan menggunakan kriteria yang berbeda; angka-angka skor menyangkut industri pengolahan pada tabel ini diperoleh dari survai pakar, yang mendasarkan pada pengetahuan/penguasaan materi tentang informasi menyangkut kriteria-kriteria yang dipertanyakan/Due to the differences is specific characteristics, the role of 
the processing industry uses different criteria; the score of values concerning the processing industry was obtained by expert surveying, which is based upon knowledge/understanding of material about the information concerning the above mentioned criteria

3. Angka-angka dengan karakter tercetak tebal pada Tabel 5 merupakan total-total skor terbesar untuk masing masing subsistem industri yang dikaji. Dari angka-angka tersebut dapat diperoleh arah pembagian peran untuk masing-masing kabupaten. Dengan kata lain, angka-angka tersebut menunjukkan pula gambaran kasar mengenai penempatan subsistem hulu dan subsistem hilir industri perikanan di wilayah yang dikaji. Dalam tampilan geografis, model pembagian peran industrial dapat dilukiskan seperti pada Gambar 11/The values with the thick printed characters in Table 5 consist of the total of highest scores for each tested subsystem industry. From the obtained values, we can see what role each regency plays. In other words, the values indicated display a rough guide on the age-old subsystem and downstream subsystem placement in the fisheries industry in the tested areas. Geographically, industrial role distribution is depicted in Picture 11

kelemahan-kelemahan pada jaringan-jaringan yang ada dan memaksimalkan kekuatankekuatan yang telah wujud sejauh ini.

7. Bahwa masing-masing kabupaten memiliki keunggulan dan kelemahan, maka optimalisasi peran perlu dipertimbangkan untuk memaksimalkan kinerja industri di masingmasing kabupaten dan secara bersama-sama dalam pola pengembangan yang terpadu

Untuk menentukan model yang akan diusuikan, Gambar 9 ditampilkan sebagai bentuk yang disederhanakan dari jejaring industri perikanan di lokasi penelitian sebagaimana dapat dilihat pada Gambar 8

Pada periode sebelum pemberlakukan otonomi daerah, interaksi tersebut telah terbangun, dengan permasalahan-permasalahan khas saat itu (ikhtisar Gambar 8). Dengan diberlakukannya UU otonomi daerah, masing-masing kabupaten 'bersaing' dan memunculkan masalah baru. Visualisasi keadaan ini dapat ditampilkan seperti pada Gambar 10, yang juga menonjolkan adanya dua permasalahan utama, yaitu ancaman terhadap sumberdaya alam dan peningkatan inefisiensi. Berdasarkan pemaparan tentang potensi dan permasalahan di atas, wujud model alternatif dapat dilukiskan seperti pada Gambar 11. Menurut konsep agribisnis, model ini mencakup subsistem industri hulu sampai hilir.

Dalam model tersebut, subsistem-subsistem tersebut mencakup kegiatan industri utama sebagai berikut: kegiatan industri penangkapan laut, penangkapan darat, dan budidaya, yang dikelompokkan kedalam industri hulu; serta industri pengolahan dan kegiatan pemasarain, yang dikelompokkan kedalam komponen industri hilir, yang diusahakan dan dikembangkan di satu wilayah dalam konteks keterpaduan.

\section{Operasionalisasi Mlodal}

Model konseptual, lebih lanjut, perlu dikembangkan menjadi model yang lebih bersifat operasional. Dalam penelitian ini, operasionalisasi dilakukan melalui prioritasi peran dari masing-masing kabupaten, dimana peran-peran industrial direkomendasikan untuk dimainkan oleh wilayahwilayah yang sesuai. Pemeranan tersebut dilakukan dengan memasukkan data-data empiris yang dikumpulkan selama kegiatan lapang, yang dikaji menurut 4 kriteria $^{5}$, yaitu nilai manfaat ekonomis, kontinuitas, stabilitas, dan pemerataan (ekuitabilitas) Hasil dari pemeranan tersebut adalah informasi tentang bidang-bidang yang sebaiknya dikembangkan di masing-masing wilayah (kabupaten). Untuk keperluan pemeranan tersebut, penelitian ini mengadopsi teknik skoring, yang didasarkan pada teori utilitas (utility theory), dimana skor suatu kabupaten untuk peran tertentu dalam konteks mode pengembangan industri secara terpadu ditentukan oleh berbagai faktor, yang tergabung dalam 4 kriteria tersebut di atas. Tabel 4 menunjukkan rangkuman dari data empiris yang dipergunakan untuk pengkajian peran sedangkan Tabel 5 menunjukkan skor-skor, yang merupakan nilai-nilai terstandarisasi dari datadata empiris tersebut.

\section{Tindak lanjut operasionalisasi model}

Model seperti ditampilkan pada Gambar 12 melukiskan keterpaduan dalam pengembangan industri, baik antar kegiatan usaha di dalam kabupaten maupun antar gugus kegiatan industri dałam satu

Keempat kriteria tersebut disarikan faktor-faktor utama dalam mempertimbangkan industri perikanan, yang dirangkum dari 列 main factors on matters of consideration in the fishing industry, which were obtained from several literatures based on how it should be formatted found in the preface of this report 


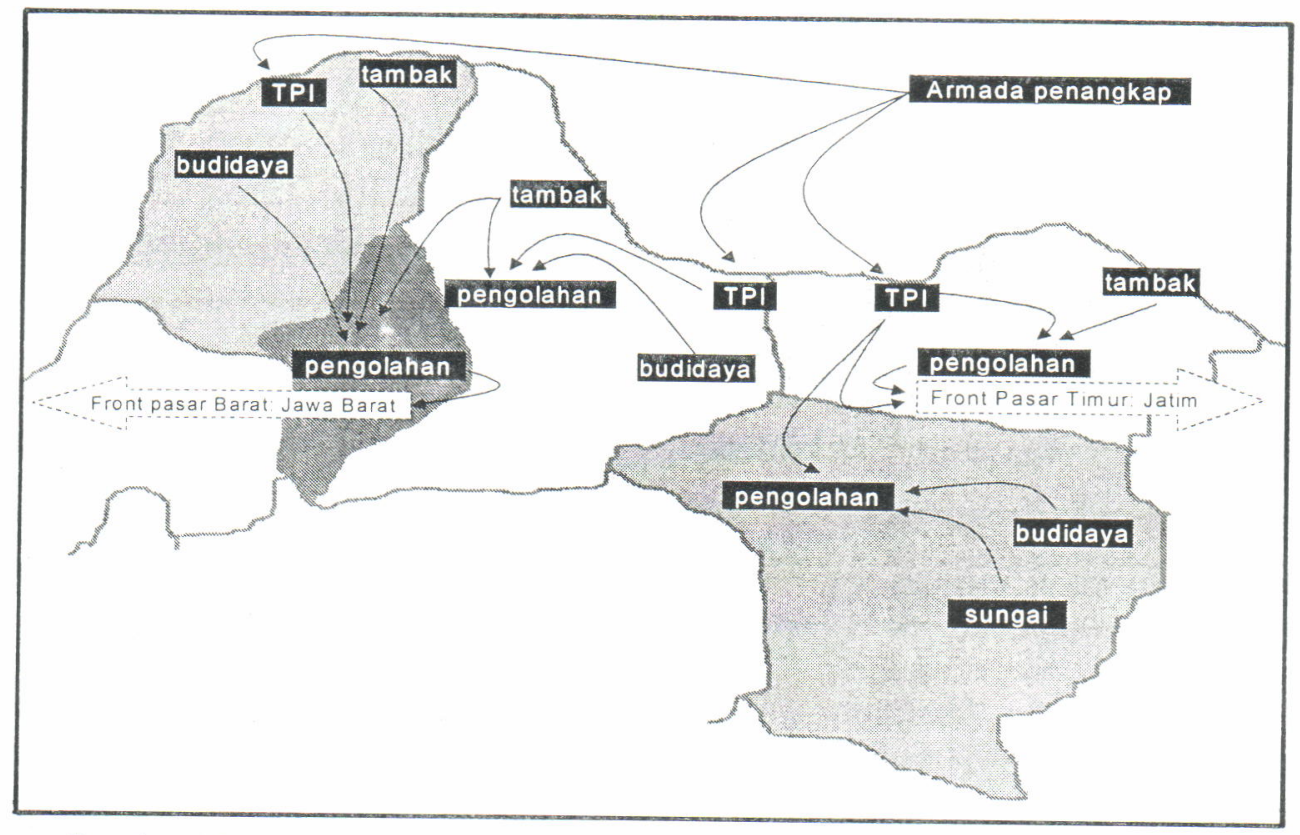

Gambar 12. Tampilan geografis pembagian peran industrial di lokasi penelitian

Figure 12. Geographical depiction of industrial role distribution in the research location

kabupaten dengan kabupaten lain. Implikasi dari telah tergambarkannya model ini adalah perlunya tahap sosialisasi, yang menyangkut di antaranya penyampaian usulan revisi program pengembangan industri perikanan di wilayah-wilayah yang akan dikembangkan. Berdasarkan hasil analisis di atas dan data terkait yang berhasil dikumpulkan, untuk wilayahwilayah dalam cakupan lokasi penelitian, usulan tersebut meliputi:

1. Pengkajian ulang program peningkatan efektivitas penangkapan laut

2. Reposisi arah pengembangan TPI dan PPI, misalnya dengan mengkhususkan TPI tertentu untuk armada tangkap tertentu, dalam rangka mengurangi dampak persaingan kontraproduktif dalam usaha penangkapan ikan laut

3. Mendorong penyelenggara pembangunan perikanan di setiap kabupaten untuk mengusahakan terbentuknya forum pemanfaatan sumberdaya perikanan (mempertimbangkan pembagian kuota, dan sebagainya)

4. Merelokasikan sebagian dana pembangunan dari perikanan laut ke perikanan darat

\section{Kegunaan dan Keterbatasan, dan Validitas Model}

Dengan adanya model seperti diuraikan di atas, masing-masing kabupaten dapat menentukan prioritas dalam pemrograman berbagai kegiatan yang yang terkait dengan pengembangan industri perikanan di wilayahnya. Model ini dapat diharapkan sebagai pelengkap untuk hasil-hasil yang diperoleh oleh peneliti terdahulu yang mengkaji pengembangan penelitian di daerah yang sama. Dan, mengingat bahwa banyak lokasi lain di Indonesia yang memiliki kesamaan atau kemiripan masalah dengan wilayah lokasi penelitian, terutama masalah-masalah yang terkait dengan lebih tangkap sumberdaya laut, otonomi daerah, dan keterbelakangan perkembangan perikanan darat, maka diharapkan model yang dikembangkan dalam penelitian ini dapat dipertimbangkan sebagai referensi bagi wilayahwilayah lain.

Disamping kegunaan tersebut di atas, perlu diungkapkan keterbatasan dari model ini. Salah satu di antaranya adalah bahwa meskipun penelitian ini menggunakan data yang valid (karena telah melalui beberapa tahapan verifikasi: pengumpulan data sekunder, wawancara, observasi lapang, dan seminar/pertemuan), kinerja model tersebut masih perlu diujicoba dalam implementasi program yang sesungguhnya.

Terlepas dari keterbatasan data mengenai aspek operasionalnya, rekomendasi yang didasarkan atas model di atas secara pasti akan memberikan nilai positif bagi pengelolaan sumberdaya perikanan Dalam hal ini, aspek manfaat, yang juga akan terkait dari implikasi dari model tersebut dapat dijelaskan menggunakan analogi fenomena overdosis: bagi seorang penderita sakit yang mengkonsumsi obat secara overdosis, akan lebih sehat apabila penderita tersebut mengurangi dosis obatnya, sebaliknya besar kemungkinan bahwa obat tersebut akan menyehatkan orang lain yang kekurangan obat. Dalam hal 
pengelolaan sumberdaya perikanan, analogi tersebut mengandung arti bahwa apabila investasi berlebih yang ditanam pada subsistem penangkapan dapat dikurangi, maka subsistem penangkapan tersebut dapat dioptimalkan dan subsistem lain mendapat peluang yang lebih besar untuk dikembangkan melalui realokasi dana yang semula diinvestasikan di subsistem penangkapan laut.

\section{KESIMPULAN}

Beberapa kesimpulan penting yang diperoleh dari penelitian ini adalah:

(1) Sejalan dengan pelaksanaan otonomi daerah, kabupaten-kabupaten telah menyusun program eksploitasi sumberdaya yang dikaitkan dengan pengembangan industri perikanan, yang pada umumnya dilaksanakan tanpa mengindahkan interaksi antara eksploitasi sumberdaya di satu tempat dengan kinerja industri perikanan di tempat lain.

(2) Berdasarkan identifikasi dan analisis terhadap faktor-faktor fisik maupun sosial yang ditemukan dalam penelitian ini, model pengembangan industri perikanan alternatif yang perlu dipertimbangkan penerapannya, baik di lokasi penelitian maupun di tempat lain dengan karakteristik serupa, adalah model pengembangan industri terpadu, yang dikaitkan dengan potensi maupun kelemahan masingmasing lokasi pada kawasan tertentu.

(3) Khusus untuk lokasi penelitian, dimana studi kasus dalam penelitian ini dilaksanakan, berdasarkan analisis terhadap kriteria-kriteria yang relevan, aplikasi dari model tersebut dapat dinyatakan dalam bentuk prioritasi peran untuk masing-masing kabupaten, sbb:

\begin{tabular}{ll}
\hline \multicolumn{1}{c}{$\begin{array}{c}\text { Subsistem Industri } \\
\text { Industry Subsystem }\end{array}$} & \multicolumn{1}{c}{$\begin{array}{c}\text { Kabupaten } \\
\text { Regency }\end{array}$} \\
\hline $\begin{array}{l}\text { Penangkapan laut } \\
\text { Marine capture } \\
\text { Tambak Udang/ } \\
\text { Brachish water ponds } \\
\text { Budidaya Kolam/Pond } \\
\text { Culture }\end{array}$ & Pati, Rembang \\
$\begin{array}{l}\text { Penangkapan Sungai/ } \\
\text { Inland capture }\end{array}$ & Pati, Rembang, Jepara, Blora \\
Pengolahan/Processing & Pati, Rembang, Kudus \\
\hline Keterangan/Note & $\begin{array}{l}\text { Subsistem industri non- } \\
\text { prioritas } \neq \text { subsistem yang } \\
\text { tidak dapat dikembangkan/ } \\
\text { Non-printing subsystem } \neq \\
\text { subsystem which cannot } \\
\text { bedeve loped }\end{array}$ \\
\hline
\end{tabular}

(4) Hasil penelitian ini dapat membawa implikasi dalam bentuk perlunya reorientasi pendekatan pengembangan industri perikanan di era otonomi, dari yang bersifat persaingan bebas ke pendekatan yang mengedepankan keterpaduan.

(5) Model ini dapat dipertimbangkan untuk diadaptasikan ke wilayah lain, dengan asumsi (limitasi) bahwa kabupaten-kabupaten / wilayah lain di Indonesia, dengan karakteristik fisik dan sosial serupa, pada umumnya mempunyai kecenderungan yang sama dalam menyikapi otonomi.

\section{DAFTAR PUSTAKA}

Anonim. 2001. Perikanan Jawa Tengah dalam Angka. Dinas Perikanan dan Kelautan Jawa Tengah.

Anonim. 2001a. Program Pembangunan Daerah (Propeda) Kabupaten Rembang 2001-2005. Pemerintah kabupaten Rembang

Anonim. 2001b. Renstrada Rembang. Pemkab Rembang

Anonim. 1998. Laporan Tahunan Perikanan Kabupaten Jepara. Dinas Perikanan Kabupaten Jepara.

Anonim. 1995. Statistik Perikanan Indonesia. Direktorat Jenderal Perikanan, Jakarta.

Anonim. 1992. Studi Kelayakan PPI di Tawang, Kendal. Pemerintah kabupaten Kendal.

Bailey, C. 1992. Coastal aquaculture development in Indonesia. In R.B. Pollnac, C. Bailey, \& A. Poernomo (eds.). Contributions to Fishery Development Policy in Indonesia. International Center for Marine Resource Development. Univ of Rode Island, Kingston, RI.

Brainerd, T. R. 1989. An evaluation of selected artisanal fisheries projects in Senegal. In R.B. Pollnac and T. Morissey (eds.). Aspects of Small-scale Fisheries Development. International Center for Marine Resource Development. Univ of Rode Island, Kingston, RI.

Fauzi, A. 1999. The Management of Competing Multispecies Fisheries - a Case Study of Small Pelagic Fishery on the North Coast of Central Java. PhD thesis, Simon Fraser University, Canada

Martosubroto, P., N. Naamin dan Malik, B.B.A. 1991 Potensi dan Penyebaran Sumberdaya Ikan di Perairan Indonesia. Dit. Jen. Perikanan, Puslitbang Perikanan dan Pusititbang Oseanologi/LIPI. Jakarta

Payne, R.L. 1973. Planning criteria for fisheries development with special reference to the Indian Ocean. Technical Conference on Fishery Management and Development, Vancouver 13-23 February.

Saragih, B. 2001. Agribisnis-Paradigma Baru Pembangunan Ekonomi Berbasis Pertanian. PT Loji Grafika Griya Sarana.

Subagio, P. 2000. Manajemen Operasi. BPFE. Yogyakarta.

Townsley, P. 1998. Social Issues in Fisheries. FAO Fisheries Technical Paper. FAO of the UN, Rome.V. 
A. H. Purnomo, S. H. Suryawati, Y. Hikmayani dan E. Reswati

Zerner, C. 1992. Development of the small-scale freshwater cage culture fishery in reservoirs in Java: Legal, environmental, and socio-economic issues. In: Pollnac, R.B., Bailey, C. dan Poernomo, A. (eds.)
Contributions to Fishery Development Policy in Indonesia. International Center for Marine Resource Development. Univ of Rode Island, Kingston, RI. 